André Hubert R., S.J.

UCN - Antofagasta

Con el auspicio de FONDECYT - CHILE

\title{
El enigma del hombre según Anselmo de Canterbury
}

Si la teología es una palabra sobre Dios, esta misma palabra tiene que ser pronunciada por el hombre. El estudio teológico debe interesarse por el hombre so pena de decir palabras en el aire, sin fundamento y, sobre todo, sin consecuencia para la vida de los hombres. Por otra parte, esta palabra sobre Dios no puede ser un simple reflejo (una proyección) del hombre o de sus ideas sobre Dios. Debe tener su fundamento en Dios mismo. Así, hablar de Dios es hablar del hombre y hablar del hombre desde Dios. ¿Puede el hombre, el teólogo, realizar tal proeza? ¿Puede el hombre hablar de sí mismo? Si el hombre quiere llegar a conocerse en profundidad debe reconocer que no se hizo, es decir, debe partir de aquel que lo creó y de la finalidad para la cual lo hizo. El hombre es misterio, enigma para sí mismo. De dos maneras: porque no puede pensarse a sí mismo en profundidad y porque no puede conocer totalmente al que lo creó. Aun así la búsqueda de sentido es importante. El hombre tiene uso de razón y debe razonar.

En esta búsqueda de sentido sobre el enigma del hombre quiero seguir a Anselmo de Canterbury (1) (1033-1109). Como todo teólogo, Anselmo quiere hablar de Dios y, para hablar de Dios, necesita hablar de la creación (2).

Llamamos comúnmente a Anselmo de Canterbury el Padre de la Escolástica porque su método permitió el nacimiento o desarrollo de la Escuela. Sin embargo, sería falso ver en él solamente un frío pensador racional (o racionalista). Anselmo es monje y su teología se inscribe también en la teología monástica, es decir una teología afectiva, orante, litúrgica (3). Es un 'místico

(1) La edición crítica de la obra de San Anselmo fue realizada por F.S. SCHMITT (Anselmi opera omnia, Stuttgard Frommann Verlag 1984) y retomada (fotocopiada) por la edición francesa de M. CORBIN (L'oeuvre de S. Anselme de Cantorbéry, Paris Cerf, 1986 ss). He utilizado la edición francesa (que no incluye todavía las cartas) para mi trabajo. La manera de citar es la siguiente: la primera cifra es el capítulo de la obra; después del punto-coma viene la página, sigue una coma y después, la o las líneas según la edición crítica. Las abreviaciones se tomaron también de la edición Corbin.

(2) Es el punto de partida de mi trabajo: Palabras de Creación. La creación en la teología y en el método teológico de San Anselmo de Canterbury, Santiago, Anales de la Facultad de Teología, 2004.

(3) Ver mis trabajos: Teología monástica y teología escolástica: el aporte de San Anselmo de Canterbury, Anales de Teología Universidad de la Santísima Concepción, 2000, pp. 45-59. Palabras de Creación. o.c., pp. 35-38. Saint Anselme à la croisée de la théologie scolastique et de la théologie monastique, in: O. MERISALO (ed.), Actes du III Congrés européen d'études médiévales, Jyvaskyla (Finlande) du 10 au 14 juin 2003, (por aparecer en 2005). 
racional' (4). Para estudiar el enigma del hombre será indispensable recordar esta doble pertenencia de Anselmo a la teología escolástica y a la teología monástica. Recordemos desde ahora que Anselmo define la teología como un Fides quaerens intellectum, una fe que busca entender. Es decir una fe que recibe todo de Dios y busca entender para creer más y mejor. Ningún creyente puede escaparse de esta fe ni de este esfuerzo aunque esté poco dotado de inteligencia (5). Aquel que, firme en su fe, puede encontrar razones de la fe, que dé gracias a Dios y si no puede, que incline su cabeza para venerar (6). Anselmo está claro: el esfuerzo para entender la fe es indispensable para esta vida y preparación para la visión beatífica: "Queremos solamente citar un pasaje de la Sagrada Escritura donde ella nos invita a buscar la razón de nuestra fe. Cuando dice 'si ustedes no creen, no entenderán', nos exhorta claramente a progresar hacia la comprensión y nos enseña cómo progresar. Entiendo la comprensión que podemos tener en esta vida como el término medio entre la fe y la visión. Por eso, estimo que más uno progresa hacia esta inteligencia, más se acerca a esta visión a la cual todos aspiramos. Animado por esta consideración y a pesar de la pobreza extrema de mi ciencia, me esfuerzo para crecer en la inteligencia de las razones de lo que creemos, en la medida que la gracia divina se digne concedérmelo. Y cuando descubro algo que antes no había visto, me apresuro en comunicarlo a otras personas para, con su juicio, aprender lo que debo retener con más seguridad" (7). En otras palabras, la reflexión del teólogo, la búsqueda de sentido, la comprensión el enigma del hombre es la manera lógica de expresar la fe en términos humanos y de prepararse para la visión beatífica. Hay en eso un esfuerzo intelectual indispensable para el creyente y un sentido escatológico de la vida humana.

\section{PUNTO DE PARTIDA}

Como punto de partida para estudiar el enigma del hombre, veamos los empleos de la palabra aenigma en la obra anselmiana. Solo aparece en el Monologion (Mon) (8).

(4) “Anselme fut un 'mystique rationnel' chez qui l'intellection et la contemplation se sont continuellement stimulées et rejointes": J.-F.COTTIER, Anima mea. Prières et textes de dévotion du Moyen Age latin, Turnhout Brepols 2002, p. xxxii.

(5) Monologion (Mon) 1; 13, 10: si vel mediocres ingenii est. Cf. Rustici: De Grammatico (DG) 11; $156,9$.

(6) Epístola de Incarnatione Verbi (Inc) 1; 7, 2-4: si potest intelligere, Deo gratias Amat; si non potest, ... submittat caput ad venerandum.

(7) Commendatio operis ad Urbanum Papam II (Com): p. 40, 7-17: Et ut alia taceam quibus sacra pagina nos ad investigandam rationem invitat: ubi dicit: "nisi credideritis, non inelligetis", aperte nos monet intentionem ad intellectum extendere, cum docet qualiter ad illum debeamus proficere. Denique quoniam inter fidem et speciem intellectum quem in hac vita capimus esse medium intelligo: quanto aliquis ad illum proficit, tanto eum propinquare speciei, ad quam omnes anhelamus, existimo. Hac igitur ego consideratio, licet sim homo parvae nimis scientiae, confortatus, a eorum quae credimus rationem intuendam, quantum superna gratia mihi dare dignatur, aliquantum conor asurgere; et cum aliquid quod prius non videbam reperio, id aliis libenter aperio, quatenus quid secure tenere debeam, alino discam iudicio. (La 'Commendatio' es la Carta de presentación y ofrecimiento del Cur Deus Homo $(\mathrm{CDH})$ al papa Urbano II. En ella, Anselmo explica sus motivos para escribir y su sentido de la teología). 
Anselmo empieza su razonamiento describiendo las cosas comunes, creadas; ellas son per aliud (por otro: Mon 1-4). Desde allí puede presentar a la Naturaleza eminente y mostrar con razones necesarias su existencia y las relaciones en Ella, relaciones definidas en el Espíritu de amor. El per aliud indica una dependencia óntica. Toda creatura nace, llega a existir porque la Naturaleza eminente le da el existir y le permite conservar este existir (Mon 13). Pero inmediatamente, Anselmo declara que esta misma Naturaleza eminente es inefable (9), es decir incomprensible (64; 75, 6-7) porque está por encima de todo (L. 7). Entonces, ¿cómo discutir algo de Dios? $(65 ; 75,20$ ss). Anselmo acepta que se puede decir algo cuando hablamos de una cosa a través de otra (per aliud). Así hablamos por enigma (L. 14); vemos una semejanza o imagen como cuando miramos a través de un espejo (10). Hablar de semejanza, de imagen o de espejo es aquí importante. Decir que soy imagen significa declarar que soy parecido al original y que, al mismo tiempo, no soy el original. Esto debe producir humildad y buscar vivir este parecido. Mi misión será no hacer lo que quiero, sino buscar profundizar el parecido con el original. El enigma y la imagen son entonces algo dinámico. En el espejo podemos ver algo, aun cuando no vemos lo propio de la cosa vista porque queda inefable. Recordemos que las palabras son equívocas: en mi mente me ayudan a entender, pero no significan exactamente lo que trasciende mi inteligencia. Esto es el sentido del enigma.

El c. 66 insiste en lo mismo: solo se puede percibir algo de la Naturaleza eminente por otra cosa $(66 ; 77,8)$. Entonces, la mejor manera de conocerla es conocer una naturaleza que se le parezca. Se debe buscar la semejanza en una naturaleza cercana porque toda esencia, por ser creada por la Naturaleza eminente, de alguna manera le es semejante. Entre todas las creaturas, solo el espíritu racional corresponde. Lo que debe hacer el hombre es estudiarse a sí mismo. El espíritu racional es para sí el espejo donde refleja la imagen de Dios $(67 ; 77,27$ ss) porque tiene memoria, inteligencia y amor (p. 78, 1-2.5.9): lo que es lo mejor y lo más grande (L. 9-10).

El c. 68 proclama que "la creatura racional fue hecha para amar a la Naturaleza eminente" (68; 78, 13) (11). Esto significa que puede discernir. Además este poder es su fuerza, porque puede amar o rechazar. Si ama a la Naturaleza eminente, vivirá

(9) INEFFABILIS: Mon 28; 46, 20-38; 56, 15.16 - 43; 59, 16-64; 75, 7 - 65; 75, 18.22.22; 76, 1.20; 77, 1-67; 78, 4-79; 85, 12 - Pr 17; 113, 7.13 - Resp 9; 138, 6.7 - CDH I, 3; 50, 30 - Proc 9; 205, 11-10; 206, 5.13 - Or 4; 12, 34-7; 20, 66 - INEFFABILITAS: Mon 65; 75, 19 (Hapax) - INEFFABILITER: Mon 57; 68, 24-80; 87, 13 - Or 16; 65, 33.

La palabra 'ineffabilitas' es hapax en la obra anselmiana. Según el estudio del adjetivo 'ineffabilis' y del adverbio 'ineffabiliter' se puede deducir lo siguiente: Anselmo habla de inefabilidad solo cuando habla de Dios y, específicamente de la Trinidad (sobre todo en el Monologion). En este mismo Monologion, Dios es inefable porque es secreto (Mon 64; 74, 36 - CDH II, 16; 117, 5.18) e impenetrable (Mon 43; 59, $16 \mathrm{ss)}$ ). Su inefabilidad viene que está por encima de todo (64; $75,7)$. Es tan inefable que ninguna palabra puede expresar exactamente lo que es; solo vemos en espejo, como un enigma $(65 ; 77,1 \mathrm{ss})$. En todo esto ya está presente el argumento del Proslogion. Pero entonces, ¿cómo hablar de Dios, decir algo de El? Puedo decir que es inefable aunque sé que la palabra 'inefable' significa que no puede decir nada (Resp 9; 138, 6-7).

(10) 'Per speculum et in aenigmate' (1 Co 13,12) está citado solamente en Mon 65; 76, 14-16-70; 81, 1. Anselmo quiere insistir en que la creatura percibe las cosas 'por otra cosa' (per aliud: 65; 76, $12.18 .22 ; 77,3-66 ; 77,8)$, lo que está dentro de su naturaleza según los primeros cc. del mismo Monologion (Mon 1-4). Cf. Agustín, De Trinitate XV, 9.

(11) (Título) Quod rationalis creatura ad amandum illam facta sit. 
feliz para siempre (c. 69) porque para eso fue creada. La finalidad de la vida del hombre es amar a la Naturaleza eminente y así ser feliz (12).

Partimos de la inefabilidad de Dios y llegamos a la cercanía, a la semejanza de este mismo Dios con el hombre que es la creatura razonable. Esta cercanía y semejanza se describen en el amor que es la finalidad para la cual fue creado. Llegamos así al punto de partida del enigma del hombre: el amor.

Anselmo conoce y medita la Biblia. La lectio divina y los estudios sobre San Pablo que hizo su maestro Lanfranco ciertamente le ayudaron. Por eso, podemos comparar lo que vimos en el Monologion con el texto original de San Pablo: "Ahora vemos en un espejo, en enigma. Entonces veremos cara a cara. Ahora conozco de un modo parcial, pero entonces conoceré como soy conocido" (1 Co 13, 12). Estamos en la tercera estrofa del himno al amor (13). Esta estrofa empieza con el amor que nunca acaba (v. 8) y termina con el amor más grande (v. 13). Toda la estrofa describe el crecimiento de lo imperfecto hasta lo perfecto, de la inmadurez (del niño) hasta la madurez del adulto, de la visión desde el espejo hasta el cara a cara. Hay un llamado a darse cuenta que siempre hay algo de inmadurez, de imperfección en nosotros mientras no alcancemos la plenitud en el cielo. La vida significa cambiar, avanzar; lo que significa riesgo. ¿Será así el cielo? Lo seguro es que hoy todo es parcial, mientras en el cielo habrá inmediatez: es el cara a cara. La estrofa termina mencionando las 3 virtudes teologales (fe, esperanza y caridad) que ofrecen un acceso directo a Dios, aunque sea imperfecto. Las 3 subsisten, es decir, entran en su perfección: la fe se transforma en visión (2 Co 5, 7) y la esperanza en cumplimiento. El amor no cambia. Ya es perfecto porque es la realización de la vida en Dios. El amor es la madre de las virtudes: todas se apoyan en él y él la utilizan (v. 7).

El cara a cara con Dios es lo que esperamos. Hoy solo vemos en espejo, en enigma. En la antigüedad, el espejo no tenía la perfección actual. Muchas veces había que adivinar lo que se veía. Pero el espejo moderno, aun en su perfección para mostrar la nitidez de los rasgos, es un sustituto: no muestra la realidad, sino su inverso: la izquierda es derecha y viceversa. Por eso, el cara a cara era y es fundamental. Eso es el significado del v. 12: lo fundamental es conocer y ser conocido. Ahora solo hay un espejo, que es enigma, el que será borrado por el cara a cara del cielo (1 Jn 3, 2). En todo, el amor es lo primero y es eterno.

Anselmo refleja las mismas ideas que Pablo. La idea de espejo (speculum) es la de una imagen inadecuada (14). Veamos 2 textos del Monologion. En un primero (Mon 65; 76, 16), Anselmo que ha mostrado la inefabilidad de la Naturaleza eminente (15), busca expresarla por otra cosa (16), es decir, por enigma (p. 76, 14; 77, 3). Y Anselmo toma un ejemplo: "Muchas veces vemos algo no con propiedad, es

(12) La finalidad está indicada en el texto por 'ad hoc' (68; 78, 24.25; 79, 2-69; 79, 13.14.1415.16.18), 'ad quod' $(69 ; 79,20-74 ; 83,6)$, 'id ad quod' $(69 ; 80,5-71 ; 81,15-72 ; 82,7-74 ; 82$, 22-23), 'ad id ad quod' $(81 ; 81,12)$.

(13) Utilizo: E. WALTER, Primera carta a los Corintios, Barcelona Herder 1977, pp. 246-252.

(14) En el De Veritate (DV), Anselmo explica el error en que pueden caer los sentidos y da como ejemplo "cuando pensamos que nuestra vista encuentra nuestro rostro en un espejo" (DV 6; 184, 27-28. aut cum putamus quod visus noster vultus nostros inveniat in speculo).

(15) Ya en 64; 75, 11-12, Anselmo declara: "una consideración superior comprende racionalmente que es incomprensible (superior consideratio rationabiliter comprehendit incomprehensibile esse).

(16) Per aliud: $65 ; 76,12.18 .22 ; 77,3-66 ; 77,8$. 
decir como es, sino por alguna similitud o imagen, así cuando consideramos la cara de alguien en un espejo" (65; 76, 14-16) (17). La unión de enigma (L. 14) y espejo (L. 16) muestra que Anselmo se refiere al texto de Pablo. El enigma parece ser todo tipo de recursos que ayuda a enterarse de algo aunque no sea en la profundidad adecuada. El espejo es uno de estos recursos, es un tipo de enigma. El problema es que "decimos y no decimos, vemos y no vemos" (L. 17) (18). De allí el problema: ¿cómo llegar a decir o ver lo real?

El c. 67 responderá. Allí está nuestro segundo texto sobre el espejo. Ya el título advierte: "la mente es su espejo y su imagen" $(67 ; 77,26)(19)$, es decir, la mente racional del hombre es espejo e imagen de la Naturaleza eminente. "Se puede decir con propiedad que la mente racional es para sí el espejo en el cual ve (speculari) para así decirlo la imagen de la Naturaleza eminente que no puede ver cara a cara" (67; 77, 27-78, 1) (20). Después Anselmo, como lo hace san Pablo, podrá presentar las 3 virtudes teologales: el amor (cc. 68-74), la esperanza (c. 75), la fe (cc. 76-78).

¿Qué podemos decir? Ciertamente, hay un parecido entre las ideas de Pablo y las de Anselmo. Pero más allá de la similitud entre ambos, hay una búsqueda de trascendencia. El hombre necesita de claves racionales para pensar. Pero al mismo tiempo, si se queda en eso, se asfixia. Necesita también de claves simbólicas (mítica, trascendente) so pena de quedarse en la inmanencia. El enigma es entonces algo enigmático, como un espejo antiguo que no deja traslucir los rasgos. Pero al mismo tiempo, el enigma refleja los deseos y esfuerzos del hombre por conocer más. Refleja también todo el dinamismo inserto en estos esfuerzos; dinamismo y esfuerzo que recibirán su recompensa en la bienaventuranza eterna cuando veremos cara a cara al Dios que buscamos y tratamos de entender. El enigma de Pablo y Anselmo es el esfuerzo por conjugar trascendencia e inmanencia. ¿Cómo expresar a Dios con palabras humanas, el Creador con palabras creadas? ¿Pueden nuestras pobres expresiones expresar el que supera toda expresión? Y al final, ¿puede la materia acoger a su Dios? El enigma del que habla Anselmo en el Monologion es el antecesor del argumento del Proslogion ( $\mathrm{Pr}$ ): Dios es eso de lo cual nada mayor puede ser pensado (Pr 2) y Dios es mayor a cualquier cosa que se pueda pensar ( $\operatorname{Pr} 15)$ (21). Hay en eso un dinamismo, un entusiasmo para la búsqueda teológica, dinamismo que encuentra su razón de ser en el sentido escatológico de la vida y encontrará su plenitud en el escatón. El 'cara a cara' es el encuentro amoroso de los amantes que se buscan: los 2 serán uno solo (Gn 2, 24 - Mt 19, 5-6).

Por eso este trabajo parte de un estudio sobre el amor en las obras de Anselmo. El amor es realmente el enigma del hombre que ayuda a acercarse al enigma de Dios. El método empleado será de seguir las palabras amare y diligere con sus

(17) Et saepe videmus aliquid non proprie, quemadmodum res ipsa est, ser per aliquam similitudinem aut imaginem; ut cum vultum alicuius consideramos in speculo.

(18) Dicimus et non dicimus, videmus et non videmus.

(19) Quod mens ipsa speculum eius et imago eius est.

(20) Aptissime igitur ipsa sibimet esse velut 'speculum' dici potest, in quo speculetur ut ita dicam imaginem eius, quam 'facie ad faciem' videre nequit.

(21) $\operatorname{Pr} 2 ; 101,5$ : credimus te esse aliquid quo nihil maius cogitari possit. Pr 15; 112, 14-15: es quiddam maius quam cogitari possit. 
derivadas y otras palabras anexas en los textos de Anselmo (22). Dividiré este estudio en 3 partes que son 3 períodos de la obra literaria de Anselmo. El primer período consta del Monologion (Mon) y del Proslogion (Pr); el segundo de los llamados libros filosóficos que Anselmo llama bíblicos: el De Veritate (DV), el De Libertate Arbitrii (DLA) y el De Casu Diaboli (DCD); el tercero incluye el Cur Deus Homo (CDH) y las obras anexas. Los demás libros pueden ser incorporados a una de estas etapas.

\section{PARTE I}

1) En el Monologion, Anselmo busca expresar su fe de manera racional para hacerla accesible a todo cristiano. El libro se divide en 3 grandes partes (23). En la primera, Anselmo busca un punto de partida desde las cosas creadas (Mon 1-4). Poco a poco, introduce la locutio (Mon 10) que después llamará el 'Verbo' de la Naturaleza eminente. En la segunda parte, Anselmo describe a este Verbo y su relación con el Padre. Entonces puede introducir el verbo 'amare' y el sustantivo 'amor'.

El c. 49 se titula: "El Espíritu eminente se ama" (49; 64, 15) (24). Antes (c. 48), había mostrado que el Padre es memoria y el Hijo inteligencia. Estamos en la Trinidad psicológica (memoria, inteligencia, voluntad o amor). Ahora, desde el c. 49, Anselmo va a dedicarse a presentar el amor en la Trinidad porque es evidente que el Espíritu eminente se ama a sí mismo (49; 64, 18-19) de igual manera como se acuerda de sí y se entiende. De la misma manera, decimos que "la mente racional se ama y lo ama por el hecho que puede acordarse de sí y de él y entenderse a sí mismo y a él" (L. 19-21) (25). Anselmo supone que una cosa que está en la memoria y en la inteligencia debe ser amada o rechazada (L. 22-23). Es su base para afirmar que el Espíritu eminente se ama a sí mismo tal como se recuerda y se entiende (L. 23-24).

La tesis del c. 50 es que este amor procede por igual del Padre y del Hijo. Anselmo pone el amor como consecuencia de la memoria y de la inteligencia y no como causa precedente (L. 3-5) porque no se puede amar cosa alguna si primero no se acuerda de ella, ni la entiende (L. 5-6.7). El amor procede entonces del Padre y del Hijo (L. 8). Pero cada uno se ama (diligere) de un amor igual (c. 51). Por eso, el amor es tan grande como lo es el Espíritu eminente (c. 52), y se puede decir que "el mismo amor es lo mismo que lo que es el Espíritu eminente y, sin embargo él mismo es Espíritu único con el Padre y el Hijo" (53; 66, 2-3) (26). El amor es el

(22) Cf. Concordancia de las palabras en anexo.

(23) Primera parte: cc. 1-28 (definición de la Naturaleza eminente y de la naturaleza creada). Segunda parte: cc. 29-64 (definición de la inefable pluralidad). Tercera parte: cc. 65-78 (La Trinidad sicológica. Finalidad de la creación de la creatura razonable). Conclusión: cc. 79-80 (Tres nescio quid). Cf. Mi trabajo: La creación en San Anselmo. La creación como clave de lectura del Monologion de San Anselmo de Canterbury, Santiago 1992, pp. 294-306, especialmente, p. 303.

(24) Título: Quod summus Spiritus se amet.

(25) Mens rationalis se et illum amare posse convincatur, ex eo quia sui et illius memor esse et se et illum intelligere potest.

(26) Título: quod idem amor sit idipsum, quod est summus Spiritus, et tamen ipse cum Patre et Filio unus Spiritus. 
Espíritu eminente (L. 5); se ama (L. 7: diligere) y no necesita de las creaturas. Pero el amor no es otro que el Padre y el Hijo y es Espíritu eminente (L. 8). No puede haber varias Esencias eminentes. Entonces el amor de ambos es una sola Esencia eminente (L. 10). Consecuencia: "el amor es Sabiduría eminente, Verdad eminente, Bien eminente, i.e. todo lo que se puede decir de la substancia del Espíritu eminente" (L. 11-13) (27).

"Así el amor procede totalmente del Padre y totalmente del Hijo y, sin embargo, es un único amor" (54; 66, 15-16) (28). No son 2 amores (L. 17.27). Además, este amor no puede ser llamado hijo de ambos $(55 ; 67,3.7 .20)$ : para quien lo contempla, no hay una semejanza transparente. Así ni el Padre, ni el Hijo es Padre o Madre del amor que nace de ellos (L. 19). El amor no es propiamente hablando ni no engendrado ni engendrado $(56 ; 67,24 ; 68,1.4 .7)$ : es 'espirado' $(57 ; 68,22.23)$. Por eso se le puede llamar 'espíritu' (p. 69, 1-2) aunque este mismo nombre designa también la substancia del Padre y del Hijo (L. 10).

El c. 59 expresa la unidad de la Trinidad: cada uno está totalmente en los otros "porque la memoria de la Esencia eminente está totalmente en su inteligencia y en su amor, la inteligencia en la memoria y en el amor, y el amor en la memoria y la inteligencia" (59; 70, 10-12) (29). En la memoria reconocemos al Padre, en la inteligencia al Hijo y en el amor al Espíritu de ambos (L. 15). Al mismo tiempo, podemos decir que "ninguno necesita del otro para recordar, entender o amar porque cada uno es memoria, inteligencia y amor" (60; 70, 19-21) (30). Pero entonces, ¿cómo se diferencia cada uno? se pregunta el c. 61. Basta recordar lo ya visto: el Padre no es el Hijo ni el Espíritu aunque sea inteligencia y amor $(61 ; 71,19)$ y el Hijo no es el Padre ni el Espíritu aunque que se acuerde de sí y se ame a sí mismo (L. 21). Cada uno, Padre, Hijo y Espíritu, es lo que es en su relación.

Pero será sobre todo en la tercera parte del libro (cc. 65-78) donde Anselmo habla del amor en Dios y en su creatura porque se dedica a estudiar la imagen de la Trinidad en la creatura racional. En el c. 65, Anselmo recuerda que es imposible conocer a Dios. Pero al mismo tiempo, tomando apoyo en san Pablo (1 Co 13, 12), recuerda que vemos en espejo, como en enigma $(65 ; 77,1 \mathrm{ss})$. Esto significa que nuevamente Dios es inefable, pero que algo podemos vislumbrar de El. Esto significa también que la realidad última del hombre está en Dios, en lo inefable (31). La realidad última del hombre es misterio.

Solo la mente humana puede recordarse, entender y amar $(67 ; 78,2)$. Es evidente entonces que hay en ella una verdadera imagen de esta esencia de la Trinidad inefable, la que consiste en la memoria de sí, la inteligencia y el amor (L. 3.5). La creatura racional recibió por naturaleza esa semejanza de la Sabiduría eminente que es recordarse, entender y amar lo que es lo mejor y lo óptimo (L. 9). Esto significa

(27) Est igitur idem amor summa sapientia, summa veritas, summum bonum, et quidquid de summi Spiritus substantia dici potest.

(28) Título: Quod totus procedat a Patre, totus a Filio, et tamen non sit nisi unus amor.

(29) Quia memoria summae Essentiae tota est in eius intelligentia et in amore, et intelligentia in memoria et in amore, et amor in memoria et intelligentia. Id. L. 12-14.

(30) Título: Quod nullus eorum alio indigeat ad memorandum vel intelligendum vel amandum, quia singulus quisque est memoria et intelligentia et amor. Id. L. 24 ss.

(31) Cf. supra. 
que "la creatura racional fue hecha para amar a la naturaleza eminente" $(68 ; 78,13)$ (32) y recordar, entender y amar al Bien eminente es lo más importante (L. 18). La creatura tiene el poder de discernir y este poder sería totalmente inútil si no amara o rechazara lo que discierne (L. 23-25). Así se ve que la naturaleza racional juzga o discierne y ama o rechaza lo que ha evaluado (p. 79, 1). Por eso, es evidente que la naturaleza racional fue hecha para amar a la Esencia eminente por encima de todo bien (L. 3). Aún más, para amar solamente a la Esencia eminente (L. 4). Y no puede amarla (L. 5), si no se esfuerza por recordarla y entenderla. Esto es el propósito del poder y querer: recordar, entender y amar al Bien eminente (L. 8).

El c. 69 saca las consecuencias: el alma que siempre ama a la Naturaleza eminente vivirá realmente feliz $(69 ; 79,11)$. El alma es la creatura racional. Es necesario que fuera hecha para amar a la Esencia eminente (L. 13), para amarla sin fin (L. 14) o para perder este amor (L. 15). Es evidente entonces que fue hecha para amar sin fin a la Esencia eminente (L. 18). Decir lo contrario sería impío.

Pero no lo puede hacer a menos que viva para siempre. En efecto, el Bien eminente y el Creador eminentemente sabio y omnipotente no puede haberla hecho para amarlo (L. 22) y aceptar que mientras lo ame verdaderamente (L. 23), permita que desaparezca al que lo ama para que entonces no lo ame más (L. 24). En esto, iría en contra de Sí mismo porque dio poder libremente al que no lo amaba para que lo ame siempre (L. 23). El ama a toda naturaleza y la ama verdaderamente (L 2526). La vida nunca será quitada del alma que se esfuerce siempre por amar la Vida eminente (L. 27). Aún más, si ama al Bien eminente y omnipotente, es normal que nunca viva de manera miserable (p. 80,3).

El amor es también la base del razonamiento de Anselmo para demostrar la inmortalidad del alma (c. 70) porque la Esencia eminente retribuye al que la ama (70; 80, 8.14). La tesis de este capítulo es que Dios que "es muy justo y poderoso retribuye al que lo ama con perseverancia, a quien, cuando todavía no lo amaba, le dio el ser para que pueda amarlo" (L. 9-11) (33). Decir que no retribuye al que lo ama (L. 11), sería aceptar que "no discierne entre el que ama y el que desprecia lo que debe ser amado intensamente" (L. 11-12) (34) o que no ama al que lo ama ni le es provechoso ser amado por él (L. 13).

Ahora, ¿en qué consiste la retribución? Es decir, ¿qué dará al que lo ama si no deja de amarlo? (L. 15-16). Sabemos que la creatura racional, que se vuelve inútil sin este amor (L. 19) supera a todas las creaturas. Entonces, nada de lo creado puede ser el premio de este amor (L. 20), sino solo lo que supera a todas las naturalezas. En efecto, "este mismo Bien que exige que se le ame, no obliga menos ser deseado por quien lo ama" (L. 21-22) (35), así como todo quien ama la justicia, la verdad y otros bienes busca ardientemente gozar de ellos (L. 22). La retribución para quien ama y desea la Bondad eminente será Ella misma (L. 24). Cualquier otra cosa no sería válida frente al amor, no consolaría al que la ama, ni podría satisfacer al que la

(32) Título: Quod rationalis creatura ad amandum illam facta sit.

(33) Iustissimus et potentissimus nihil retribuat amanti se perseveranter, cui non amanti tribuit essentiam ut amans esse posset.

(34) Non discernit iustissimus inter amantem et contemnentem id quod summe amari debet.

(35) Idem ipsum Bonum quod sic se amari exigit, non minus se ab amante desiderari cogit. 
desea (L. 26) porque significaría que quiere ser amado por esta otra cosa (per aliud) y no por sí (L. 28). Por eso, "el alma racional que se esfuerce por amar y desear la felicidad eminente la recibirá algún día para gozar de ella” (L. 29-31) (36). Así vivirá feliz gozando y no podrá no amar la felicidad eminente ni ella abandonar al que la ama (p. 81, 4). Toda alma que comenzó a gozar de la bienaventuranza será feliz eternamente. De lo contrario, el alma que no ama el Bien eminente incurre en la miseria eterna $(71 ; 81,9-10.21)$ porque toda alma es inmortal (c. 72).

¿Cómo podemos juzgar qué alma ama o desprecia eso para lo cual fue hecha para amarlo? (74; 82, 22-23; 83, 2). Para los mortales es imposible. Solamente podemos decir que todo hombre debe tender de todo su corazón, alma y mente a amar y desear al Bien eminente (L. 8). Pero no se puede amar o esperar lo que no se cree $(76 ; 83,16)$. Y es necesario creer la Esencia eminente y las cosas sin las cuales ella no puede ser amada (L. 18) para que creyendo estas cosas, tendamos hacia ella (in illam).

El premio recibido será Dios mismo que es el Bien eminente. No se trata solamente de tender hacia la Naturaleza eminente (tendere ad illam), sino de tender en ella (tendere in illam), es decir se trata de alcanzarla no desde fuera, sino quedándose en ella (76; 83, 27-28). Es lo que Anselmo llama 'creer en ella' (credere in illam: $76 ; 84,2)$.

El c. 78 diferencia la fe viva de la fe muerta y afirma que "la fe es inútil y como un peso muerto si no vale o vive por la dilección" (78; 84, 16-17) (37). La fe es consecuencia del amor. Por eso, debe estar acompañada por la dilección (L. 18) porque esta dilección es la que le permite actuar (L. 20). El desarrollo se hace de la siguiente manera: quien ama a la justicia eminente (L. 21) no puede aceptar lo injusto. La dilección es lo que da vida y lo que hace que la fe sea activa (L. 21) y no ociosa (p. 85, 1). Así como la ceguera es no solo perder la vista, sino no tenerla cuando debería tenerla (L. 2-3), así la fe sin dilección es una fe muerta, no porque perdió la vida que da la dilección (L. 4), sino porque no la tiene cuando debería tenerla. Se puede decir que "la fe viva cree en eso en que debe creer y la fe muerta solamente cree lo que debe creer" (L. 8-9) (38).

Anselmo explica que 'tender hacia ella' (preposición $a d$ ) debe reemplazarse por 'tender en ella' (preposición in con acusativo). Esto significa que no es solamente una dirección, una finalidad (ad); es tratar de alcanzar a la Esencia eminente, de conocerla y de perderse en ella (in). Por eso, el c. 78 expresa esta tensión con la dilección. El primer mandamiento, citado en $74 ; 83,7-8$, es lo que hace que la fe alcance su objetivo: poseer al Bien eminente Por eso, toda naturaleza "debe venerar amando y amar venerando" $(80 ; 87,10)$ (39) a Dios que no solo es Dios, sino el único Dios inefablemente trino y uno (L. 12-13). Así termina el Monologion.

¿Qué nos enseñó el Monologion? Nos enseñó en primer lugar, que la fe es consecuencia del amor. La fe sin amor es una fe muerta (c. 78). Toda vida de fe es

(36) Omnis anima rationalis, si quemadmodum debet studeat amando desiderare summam beatitudinem, aliquando illam ad fruendam percipiat.

(37) Inutilis erit fides et quasi mortuum aliquid, nisi dilectione valeat et vivat.

(38) Viva fides credere in id in quod credi debet, mortua vero fides credere tantum id quod credi debet.

(39) Debet diligendo venerari et venerando diligere. 
vida de amor y, porque es vida de amor, busca perderse en su amado. El Cantar de los Cantares está muy presente en su mente así como la unión de St 2, 20 (la fe muerta) y Gal 5, 6 (fe y amor). Podemos también añadir 1 Jn 4, 8 (Dios es amor) y Rm 5, 5 (el amor derramado en nuestros corazones). El Monologion que, a muchos, les parece racionalista, se convierte en un canto de amor. Anselmo utiliza las palabras 'amor' para hablar de Dios (que es Amor) y de su imagen (que vive de este amor) y dilectio que es el amor actuando en este mundo.

En segundo lugar, ¿dónde quedó el enigma del hombre? El Monologion es ciertamente un 'de Trinitate'. Por eso, en su reflexión, Anselmo siempre parte de Dios y nos invita a seguirlo. Pero al mismo tiempo nunca se aleja de una reflexión sobre la creación y especialmente sobre el hombre. Y esta reflexión muestra un tinte escatológico. El hombre es imagen de la Naturaleza eminente porque tiene memoria, entendimiento y voluntad (o amor). Esta imagen, para Anselmo, no es una figura poética o noética. Es sobre todo un dinamismo que hay que vivir en el amor para toda la eternidad (Mon $70 \mathrm{ss}$ ).

Recordemos: cuando digo que soy imagen, quiero significar que soy parecido al original, pero, al mismo tiempo, que no soy el original, es decir que debo poner todos mis esfuerzos en parecerme a este original y no hacer lo que quiero. Por eso, Anselmo insiste en el conocerse. Conocerse es darse cuenta ahora que veré a Dios cara a cara y que conoceré como soy conocido. Conocerse es un esfuerzo teológico. Nuevamente, el amor lo resume todo.

2) El Proslogion (Pr) es la continuación del Monologion. El c. 1 es una larga oración. Anselmo expresa su deseo de ver el rostro de Dios (40) y el fracaso de esta búsqueda por culpa del pecado. El está ansioso por el amor de Dios y se encuentra lejos de él (1; 98, 9); desea encontrarlo amándolo y amarlo encontrándolo (p. 100, 11). Sabe que Dios creó en él su imagen para que le recuerde, piense y ame (L. 13). Finaliza renovando el deseo de "entender de alguna manera tu verdad que cree y ama mi corazón” (L. 17) (41). Recordemos que, desde el Monologion, el vocablo 'creer' expresa la tensión del creyente para alcanzar y poseer el Bien eminente y que la fe no puede apartarse del amor.

El c. 9 habla del perdón de los pecados y Anselmo exclama: “¡o inmensidad de la Bondad de Dios, con qué afecto deben amarte los pecadores!” (9; 107, 23) (42). El afecto es el movimiento del alma (43).

El c. 23 busca expresar la Trinidad y hablando del Espíritu Santo repite y profundiza lo que vimos en el Monologion: "Este Bien es el amor único y común a Ti y a tu Hijo, i.e. es el Espíritu Santo que procede de ambos" (23; 117, 11-12) (44).

(40) Buscar (Quaerere, requirere) y desear (Desiderare, Invenire, Sperare, Velle) son palabras muy importantes en el Proslogion (especialmente en los cc. 1 y 18).

(41) Aliquatenus intelligere veritatem tuam, quam credit et amat cor meum.

(42) O inmensitas bonitatis Dei, quo affectu amand es peccatoribus!

(43) AFFECTUS significa los movimientos del alma en general; no se relaciona necesariamente con el afecto-amor. Concordancia: Mon 49; 64, 18 - Pr 8; 106, 12-9; 107, 23-10; 109, 4.

(44) Hoc ipsum est amor unus et communis tibi et Filio tuo, id est Sanctus Spiritus ab utroque procedens. 
Este amor es igual a ambos (L. 12) "porque tu te amas a ti y a tu Hijo, él te ama a Ti y a Sí mismo tanto como Tu eres y como El es” (L. 13-14) (45).

Los últimos cc. del Proslogion comparan los bienes terrenales con los eternos que son los bienes buscados y deseados. En cuanto a la ciencia, declara que "si es amable (si puede ser amada) la sabiduría en el conocimiento de las cosas creadas, cuánto más es amable (digna de amor) la Sabiduría que creó todo de la nada" (24; $118,5-7)$ (46). Sabemos que hay que amar el Bien único en quien son todos los bienes y que esto basta $(25 ; 118,16-17)$. Por eso, Anselmo se exclama "¿Qué amas, carne mía, qué deseas, alma mía? Allí está, allí está todo lo que amáis y todo lo que deseáis" (L. 18-19) (47). Así si deseamos belleza, vida larga, saciedad, sabiduría, Dios nos llenará. "Si es amistad, amaremos a Dios más que a nosotros mismos y cada uno amará a los demás como a sí mismo y Dios los amará más que ellos mismos a sí mismos porque ellos lo amarán y se amarán a sí mismos y a los demás por El y Dios se amará y los amará por sí mismo" (p. 119, 4-7) (48). Así será la vida eterna.

Si buscamos la verdadera seguridad: estarán asegurados de no faltar del único Bien y sobre todo están seguros que Dios que los ama (dilectorem) no les quitará este bien contra su voluntad si ellos lo aman (dilectoribus) (L. 17). Si hablamos de alegría: si otra persona a quien amarías de manera absoluta como a ti mismo tuviera tu misma felicidad, eso duplicaría tu alegría (p. 120,5). La alegría y el amor van juntos: la alegría por lo que tienen los demás depende del amor que se les tiene (L. 8-9). Y eso es la perfecta caridad (49): nadie ama a otro menos que a sí mismo (L. 10), donde cada uno ama al otro tanto como se alegra de su felicidad (L. 14). Y cada uno amará a Dios muchísimo más que a sí mismo y a todos los demás consigo (L. 15). Por eso, el mandamiento de amar a Dios con todo el corazón, toda la mente y todo el alma (L. 17). Así todo el corazón, mente y alma no bastarán para la dignidad de la dilección (L. 19).

El c. 26 profundiza. La alegría va a la par con el amor $(26 ; 121,9)$ y el amor a la par con el conocimiento (L. 9-10). “¿Hasta qué punto te conocerán entonces, Señor, hasta qué punto te amarán?" (L. 10-11) (50). Es imposible darse cuenta ahora hasta qué punto conocerán a Dios y lo amarán en aquella vida (L. 12-13). Por eso, la petición: "Ruego, o Dios, que te conozca, que te ame para alegrarme en Ti" (L. 14)

(45) Qui tantum amas te et illum, et ille te et seipsum, quantus es tu et ille.

(46) Si amabilis est sapientia in cognitione rerum conditarum: quam amabilis est sapientia quae omnia condidit ex nihilo?

(47) Quid enim amas, caro mea, quid desideras, anima mea? Ibi est, ibi est quidquid amatis, quidquid desideratis.

(48) Si amicitia: diligent Deum plus quam seipsos, et invicem tamquam seipsos, et Deus illos plus quam illi seispsos; quia illi illum et se et invicem per illum, et ille se et illos per seipsum.

(49) La 'caritas' significa el amor a Dios y al prójimo (Cf. Agustín, Enarraciones in Ps 31, 5: el amor a Dios y al prójimo se llama caridad. El amor del mundo se denomina concupiscencia). Anselmo utiliza pocas veces la palabra 'caritas'. Además de este único empleo en el Proslogion, ver Mon prol; 7, 19: Anselmo afirma que empezó a escribir su libro impulsado por la caridad de sus hermanos, es decir el amor hacia ellos (propter eorum caritatem). Cf. La definición de San Agustín: amor rerum amadarum, caritas vel dilectio (De diversis quaestionibus 83, 33: la caridad o dilección es el amor de las cosas que deben ser amadas).

(50) Quantum te cognoscent, Domine, tunc, et quantum te amabunt? 
(51). “Que progrese aquí en mí el conocimiento de Ti y que allá se haga pleno, que tu amor crezca aquí en mí y allá sea pleno para que aquí mi alegría sea grande en esperanza y allá sea plena en realidad" (L. 16-18) (52). Aquí recibimos al Hijo de Dios como consejero. Anselmo pide para terminar que "mi corazón lo ame y que mi boca lo anuncie" (L. 23-24) (53).

Como en el Monologion, la fe se une con el amor y la imagen (c. 1) y presenta un tinte escatológico (cc. 24 ss). Además se trata de 'entender'. Intelligere es más que el solo entender intelectualmente. Es intus-legere, i.e. leer desde adentro, desde el corazón; es entrar en lo que se lee (54). Entender la Verdad es entonces fundirse en esa Verdad que es Cristo (Jn 14, 6). Cristo da sentido al Proslogion. Solamente con El podemos entender el famoso argumento del c. 2 (55). Solamente con El podemos entender los últimos capítulos (cc. 24-26) donde está presente como 'el Hijo' (26; 121, 18), 'el admirable consejero' (26; 121, 20). Con Cristo podemos acoger las verdades escatológicas: allí el conocimiento y el amor alcanzan su perfección. La fe viva crece en el amor para llegar a ser plena y vivir plenamente en la realidad del cielo con Dios. Allí y solamente allí se resuelve el enigma del hombre.

3) Durante este mismo período, Anselmo escribió varias cartas. Era prior de su monasterio y sus cartas muestran su manera de relacionarse y reflejan sus preocupaciones. Para profundizar lo visto y mirarlo con un prisma diferente, vamos a ver las cartas de Anselmo a su amigo Gondulfo (56). Este era monje de Saint-Etienne. Lanfranco lo llevo consigo cuando fue nombrado arzobispo de Canterbury. Gondulfo fue obispo de Rochester en 1077 y murió en 1108.

En una primera carta (Ep. 4), Anselmo define su amistad utilizando el Salmo 137: "Que mi lengua se me pegue al paladar si no me acuerdo de ti, si no pongo a Gondulfo como lo primero de mi amistad" (L. 11-13) (57). Y explica claramente que no se trata de su padre, que también se llamaba Gondulfo, sino de su amigo (L. 13-14). Insiste en que no lo olvida: su nombre está sellado en su corazón (L. 15). Le pide no quejarse si recibe pocas cartas, las que espera con tanto amor (L. 17). Sabe que Gondulfo lo quiere y si está callado, "Tú sabes que te amo" (L. 19) (58). Entre ambos hay conciencia de este amor mutuo y de la alegría mutua (L. $21 \mathrm{~s}$ ).

En el encabezamiento de sus cartas, Anselmo indica el propósito de ellas. En la Ep. 7 a Gondulfo, Anselmo escribe solamente los nombres: "Anselmo a Gondulfo" (L. 1) (59). Pero inmediatamente explica: "mi querido amigo, quise apuntar muy

(51) Oro, Deus, cognoscam te, amem te, ut gaudeam de te.

(52) Proficiat hic in me notitia tui, et ibi fiat plena; crescat amor tuus, et ibi sit plenus: ut hic gaudium meum sit in spe magnum, et ibi sit in re plenum.

(53) Amet illud cor meum, sermocinetur os meum.

(54) K. BARTH, S. Anselme, Genève Labor et Fides 1985, pp. 36-37. Cf. P. GILBERT, Prouver Dieu et espérer en lui, NRT 1996, p. 707.

(55) Por eso, me parece mal nombrado cuando se le llama 'ontológico'.

(56) Para lo siguiente, ver mi trabajo: Saint Anselme à la croisée de la théologie scolastique et de la théologie monastique, o.c.

(57) Adhaereat lingua mea faucibus meis, si non memor sum tui, si non proposui Gondulfum in praecipuis amicitiae meae. Cf. Sal 137, 6.

(58) Tu scis quia amo te. Cf. Jn 21, 16.

(59) Gundulfo Anselmus. La misma introducción está en las Ep. 16, 2; 28, 1-2; 34, 1; 41, 1; 59, 1. 
brevemente mi saludo a tan grande amigo, yo el querido, porque no pude insinuar con más riqueza mi afecto al amado. Quienquiera que conoce bien a Gondulfo y Anselmo, cuando lee 'a Gondulfo, Anselmo' no ignora lo que hay bajo estas palabras y cuánto afecto subentienden" (L. 2-6) (60). La amistad entre las 2 personas cambia toda la vida de ambos. Y puede terminar su carta: "Así es, amigo muy dulce porque muy verdadero. Animo. Si no puedes olvidarme, recuérdame por lo menos como tu siervo, tu amigo, tu querido" (L. 42-43) (61).

Las demás cartas presentan ideas parecidas: amor profundo entre ambos amigos. Muchas veces, Anselmo se rebaja para exaltar a Gondulfo (Eps. 16; 34); insiste sobre su flojera para escribir (Eps. 41; 59; 68; 141) para dar gracias por los regalos recibidos (Eps. 34; 68; 141). Pero, ¿necesita el amor escribir? (Ep. 59). En la Ep. 28, Anselmo quiere explicar que su amor nunca disminuyó y da como prueba la presencia de Gondulfo en su mente cuando estaba escribiendo las 3 oraciones a María (62). Otro hermano le había pedido escribiera una Oración a María. "Cuando este otro hermano me lo pedía, él estaba presente, pero su petición venía desde fuera; tú estabas ausente y me persuadías desde lo interior" (L. 8-9) (63). Por eso le envía las Oraciones, "que fueron escritas a tu intención" (L. 14) (64). Después puede explicar cómo leer las Oraciones (L. 15 ss). Anselmo retomará estas ideas para el prólogo de la edición de sus 'Orationes sive Meditationes', unos 30 años más tarde (65).

El 19 de marzo 1077, Gondulfo es ordenado obispo de Rochester y lo seguirá siendo hasta su muerte en 1108. Desde la Ep. 78, el tono de las cartas cambia: ya no escribe al hermano, sino al padre (L. 1.7.38) o 'vuestra santidad' (L. 4.14.30). Le exhorta a vivir su nueva misión no como una tribulación, sino con paciencia y temor de Dios.

En la Ep. 91, Anselmo retoma su estilo: se rebaja para elevar a Gondulfo. Sin embargo el cariño mutuo los hace cercanos. El episcopado de Gondulfo no es motivo suficiente para alejarlos. "Somos un solo corazón a causa de la igualdad y cercanía del cariño" (L. 11-12) (66). Además con la amistad, cada uno saca mucho provecho. "El que ama saca más provecho para sí que para el otro" (L. 24-25) (67).

Durante los 2 exilios de Anselmo, entonces arzobispo de Canterbury, Gondulfo tuvo que encargarse de todos los asuntos de la arquidiócesis de Canterbury, tanto en lo espiritual como en lo material. Además fue el representante de Anselmo para tratar de reconciliarlo con el rey. Las cartas entre ambos reflejan más las preocupaciones materiales, políticas o espirituales que la profundidad de la amistad. Pero esta

(60) Ideo tam amicus tam amico salutationem meam tam breviter praenotare volui, quia sic dilectus affectum meum opulentius intimare non potui. Quisquis enim bene novit Gundulfum et Anselmum, cum legit 'Gundulfo Anselmus', non ignorat quid subaudiatur vel quantus subintelligatur affectus.

(61) Vale, vale, amice, ideo dulcissime, quia verissime; vale, et mei certe servi tui, certe amici tui, certe dilecti tui, si oblivisci non potes, reminiscere.

(62) En la edición final de las Oraciones, son las Oraciones 5, 6 y 7.

(63) Quod cum ipsi praesens rogaret exterius, tu absens persuadebas interius.

(64) Accipe igitur eas, quae factae sunt tua intentione.

(65) Cf. Prologus p. 3 (que retoma la carta a la Condesa Matilde: p. 4).

(66) Semper unum cor sumus propter parem dilectionis familiaritatem.

(67) Scitote quia plus sibi prodest quam alii. Prodesse: L. 15.16.18.19.24.24-25. 
amistad está siempre vigente (68). Anselmo agradece varias veces a Gondulfo por su buena voluntad. Esta 'buena voluntad' parece ser la nueva traducción de la 'caridad fraterna' (Eps. 299; 300; 314; 330). Reconoce que confía más en Gondulfo que en sí mismo (Ep. 300, 11). Lo llama "el antiguo y siempre nuevo amigo, amigo verdadero y querido en Dios" (L. 1-2) (69).

Una última mención de Gondulfo en la Ep. 355. Algunos monjes quieren viajar para visitar a Anselmo en su exilio. Este no los entusiasma a viajar. Si se trata de buscar consuelo espiritual, "tenéis al prior Ernulfo, hombre espiritual, en el cual abunda por gracia de Dios la buena voluntad y la sabiduría. Recurrid a él como a mí. También concedo esto al señor obispo Gondulfo, si alguien quisiera" (L. 17-21) (70).

¿Qué pensar de esta amistad que puede parecer muy extraña para nuestra mentalidad moderna? Para entender a Anselmo, hay que recordar el modo de vida de los monjes medievales. Para ellos, la verdadera vida es la del cielo. Allí la amistad será plena, el compartir y la comunión serán como los describen el último capítulo del Proslogion. Ciertamente hay una influencia del Cantar de los Cantares que habla de unión espiritual y para eso, emplea términos de amor físico (71). La amistad es un placer físico y, en el cielo, llegará a su grado máximo al igual que todos los placeres físicos. Este mundo es importante no en sí mismo, sino porque representa y prepara la eternidad (72). ¿No es eso el sentido del reino de Dios que Cristo vino, viene y vendrá a establecer?

¿Hay algo más humano que la amistad? En ella está el enigma del hombre. Para Anselmo, como para sus contemporáneos, vivir la vida en Dios (somos ciudadanos del cielo) y conocerse realmente (somos ciudadanos de la tierra) son 2 aspectos inseparables. Este primer recorrido nos ha insistido en eso. Podemos ahora dar un paso adelante.

(68) Las cartas son: Eps. 287, 293, 299, 300, 306, 314, 316, 330, 359, 374, 381.

(69) Antiquo et semper novo et vero amico et in Deo dilecto.

(70) Habetis vobiscum... dominum priorem Ernulfum, virum spiritualem, in quo et bona voluntas gratia Dei abundat et sapientia... Ad illum quasi ad me recurrite... Hoc etiam concedo de domno episcopo Gundulfo, si quis voluerit.

(71) Para el sentido de la amistad en Anselmo, ver los 2 libros de R.W. SOUTHERN, Saint Anselm and his biographers, Cambridge, University Press 1963, pp. 67-76, y Saint Anselm. A Portrait in a landscape, Cambridge University Press 1993, pp. 138-165.

(72) Por eso, Anselmo ve la vida monástica como la antesala ideal del cielo. Esto da el sentido del desprecio del mundo. Por ejemplo en la Ep. 120, Anselmo busca convencer a 2 primos suyos de ingresar en su monasterio. Los términos y argumentos pueden chocar nuestra sensibilidad: "Mi boca anhela vuestros besos, desea vuestra cercanía para todo lo que queda de mi vida para que en la alegría de la vida futura mi alma se alegre con vosotros" (L. 10-12: Anhelat ad oscula vestra os meum, desiderat conversationem vestram quidquid restat de vita mea, ut in pleno gaudio futurae vitae vobiscum gaudeat anima mea). Y más adelante: "Sepáis que pasará el mundo y su deseo. Sin embargo Dios permanecerá con toda su gloria. Quien ama al mundo corteja la vanidad y conseguirá una indigencia miserable. Quien desprecia al mundo y elige a Dios, sigue la verdad y encontrará la satisfacción bienaventurada" (L. 20-24: Scitis, dilectissimi mei, quia mundus transibit et concupiscentia eius -1 Jn 2, 17-, Deus autem permanebit et omnis gloria eius. Qui ergo diligit mundum, sectatur vanitatem et consequetur miseral indigentiam; qui autem contempto mundo elegit Deum, sequitur veritatem et inveniet beatam sufficientiam). Y al final, en oración a Cristo, exclama: "Promételes que, cuando vengas a juzgar, se sentarán contigo y juzgarán contigo" (L. 46-47: Promitte illis quia, cum veneris iudicare, sedebunt tecum et iudicabunt tecum). 


\section{PARTE II}

Después del Proslogion, en sus tratados, Anselmo parece haber olvidado su afectividad: los verbos 'amare', diligere y derivados tienen poca relevancia (73). En el De Veritate (DV), los verbos 'amare' y diligere entran en un ejercicio de estilo (74). En el De Libertate Arbitrii (DLA), 'amare' describe el amor de un perro por sus cachorros (c. 13) o del discípulo que alaba una explicación (c. 7). El De Casu Diaboli (DCD) se queda a nivel psicológico. Solo habla del amor de las comodidades (c. 12), del amor por la justicia unido al temor por el castigo (cc. 23-24).

En la primera parte, el amor lo resumía (casi) todo. Daba sentido a la imagen y esta imagen es la prefiguración de la vida bienaventurada. Por eso, la amistad es importante y es fundamental tener muchos amigos para vivir desde ahora la realidad del cielo. Pero queda el problema de la verdad y de la retribución. ¿Qué es la verdad? Es decir: ¿cómo decir que Dios es la Verdad y, al mismo tiempo, decir que la verdad está en las cosas? ¿Qué es la retribución? Es decir: ¿cómo unir misericordia y justicia? Dios debe perdonar, pero ¿sin castigar? El enigma se transforma, se profundiza.

Si antes Anselmo veía el enigma unido al espejo (preparando el 'cara a cara'), ahora profundiza su visión del hombre concreto. Anselmo escribió y publicó juntos 3 libros que el llama "3 tratados que se puede aprovechar para el estudio de la Sagrada Escritura" (75). El De Veritate (DV) entrega una definición de la verdad y de la justicia. El hombre es un ser libre: el De Libertate Arbitrio (DLA) nos introducirá en esta libertad. Pero el hombre usó mal de su libertad y cometió el pecado: ¿cómo puede un ser creado para el bien y el amor ser esclavo del pecado? se preguntará en el De Casu Diaboli (DCD). Esta parte concreta del ser humano, Anselmo la llama la 'rectitud' (rectitudo).

¿Qué es la verdad? (Jn 18, 38). Quizás en nuestro lenguaje hay un deseo de estudiar, de razonar. Entonces la pregunta ‘¿qué es la verdad?' se transforma en una búsqueda racionalista, noética. Por ejemplo, la definición de santo Tomás (adaequatio rei et intellectus) une la cosa y la inteligencia. La palabra que yo pronuncio me une con la cosa en su ser cosa y entonces puede haber adecuación (76). Pero ¿dónde está la verdad? ¿en la palabra o en la cosa? La cosa causa la verdad; no es la verdad. La palabra tampoco lo es, porque puede ser verdadera o falsa. Anselmo podría estar de acuerdo con la definición del Aquinate en el c. 2 del De Veritate, pero inmediatamente muestra que hay que superar esta definición. Además podemos aceptar que la verdad esté en el más allá (sea el mundo de las ideas de Platón o en el cielo

(73) La excepción será las Oraciones que estudiaré más adelante.

(74) En el c. 8 para amare; en el c. 12 para diligere.

(75) DV Praefatio; 173, 2: Tres tractatus pertinentes ad studium sacrae scripturae. Estos 3 libros se conocen generalmente como libros filosóficos. Anselmo los llama bíblicos por 2 razones. En primer lugar, porque cada uno se asienta en alguna frase evangélica (1 Co 4, 7: “¿qué tienes tú que no hayas recibido?" está en los 3 libros -Jn 8, 34: "el que comete el pecado es esclavo del pecado" es fundamental para el DLA- Jn 8, 44: "el diablo no se mantuvo en la verdad" permite comprender el DCD). Pero hay otra razón. En estos libros, Anselmo quiere expresar la verdad contenida en la Biblia en expresiones racionales.

(76) CORBIN M., Introduction (au DV), In: CORBIN Tome 2, p. 110. 
cristiano). Pero esta perspectiva (que también es racional) tiene el peligro de dar énfasis a este más allá y de reconocer a este mundo solamente como un mundo en apariencia, de segunda clase; lo que sería una negación de este mundo. ¿Puede la verdad negar la realidad?

Para Anselmo, como para la Biblia, la verdad es Dios (DV 1) (77) o es Cristo (DV 4 - Jn 14, 6) (78). Esto significa que la verdad no es algo que debe descubrir la inteligencia. La verdad es una persona. Y el encontrar la verdad depende de la relación con esa persona.

El De Veritate parte reconociendo que Dios es la Verdad. Pero ¿cómo definir la verdad que contempla el hombre? Hay muchas verdades. Anselmo, desde DV 2, une verdad con rectitud $(2 ; 178,8-26)$ y, después de analizar varios tipos de verdades, define la verdad como la rectitud perceptible a la sola mente $(11 ; 191$, 19-20) (79).

La rectitud es hacer lo recto o lo correcto. 'Solo a la mente' para distinguir de la rectitud visible $(11 ; 191,23-24)$. 'Perceptible' merece que nos detengamos. El adjetivo perceptibilis se emplea solamente en el De Veritate y en la definición de la Verdad (que se repite 3 veces). El verbo 'percipere' (80) nos ayudará.

Para Anselmo, percibir (percipere) es recibir algo, pero no a través de los 5 sentidos corporales. Solo la mente racional percibe (Mon 15; 29, 24). Por ejemplo, puede percibir la Esencia eminente; pero solo percibe que está presente y no está contenida $(22 ; 40,32)$. También puede percibir la eternidad: podemos decir que no tiene límites $(24 ; 42,27)$. Pero no podemos percibir la esencia de la Naturaleza eminente $(66 ; 77,7)$, ni nada que le sea propio. En fin, el alma racional podrá vivir la bienaventuranza, es decir "la percibirá para gozarla" $(70 ; 80,31)(81)$.

Es difícil saber si 'percipere' viene etimológicamente de 'per-capere', es decir tomar (capere) de manera perfecta (per), o de per-accipere, es decir de recibir (accipere) de manera perfecta (per). El primer sentido insiste en la voluntad y fuerza del sujeto que toma; el segundo sobre la pasividad en recibir, aceptar. El segundo sentido parece más seguro, porque, al igual que los sentidos, la mente 'percibe', recibe los impulsos desde las cosas (82). Además Anselmo cita varias veces 1 Co 4, 7: “¿Qué tienes que no lo hayas recibido? Y si lo has recibido, ¿a qué gloriarte como si no lo hubieras recibido?" (83). Lo único seguro es que el percibir es una actividad de la mente humana. Por eso, el De Veritate retoma la misma idea: el ojo ve una línea recta, pero todo otro tipo de rectitud solo está percibido por la mente (DV 11;

(77) DV 1; 176, 4: Deum veritatem esse credimus (creemos que Dios es la verdad).

(78) DV 4; 180, 21: Sed et in voluntate dicit veritas ipsa veritatem esse (La verdad misma dice que la verdad está en la voluntad). Anselmo sigue en eso una costumbre de Agustín.

(79) Veritas est rectitudo mente sola perceptibilis.

(80) PERCIPERE: Mon 15; 29, 24-22; 40, 32-24; 42, 27-48; 63, 17-66; 77, 7-70; 80, 31 - Pr 17; 113,11 - DV 11; 191, 18.24-12; 193, 2 - DCD 10; 247, 7 - Inc 1; 8, 16 - CDH I, 25; 96, 3 - Conc III, 6; 270, 24 - Or 3; 10, 15 - Med 3; 86, 73 - PERCEPTIBILIS: DV 11; 191, 20-12; 192, 7-13; 196, 29.

(81) Aliquando illam ad fruendum percipiat.

(82) Por ejemplo: Or 3; 10, 15-16: Fac me, Domine, ita ea ore et corde percipere atque fide et affectu sentire (Haz, Señor, que los perciba - o reciba- de boca y corazón y que los sienta por la fe y el afecto).

(83) DCD $1 ; 233,3.6 ; 235,15-3 ; 236,11-12 ; 22$, 14. Además DLA 3; 211, 20 - Conc III, 1; 263, 10-3; 267, 4-5. 
191, 18 s) (84). De allí la definición de la verdad que hemos visto. La percepción es entonces el 'sexto' sentido que pertenece solamente a la naturaleza racional y le permite 'percibir', es decir captar, recibir algo a través de la mente. La primera percepción es la rectitud (o verdad o justicia, porque las 3 están muy unidas) (85).

Volvamos a la definición de la Verdad. Parece una definición racional (o racionalista), sobre todo cuando habla 'de la sola mente'. Sin embargo, recordemos que 'perceptible' significa recibido y aceptado (¿de dónde?): la verdad es algo que hay que recibir. Además la rectitud es el actuar correcto. Aquí es el actuar correcto para recibir. Ya en el Monologion, Anselmo había expresado esta idea hablando del amor: el ser humano puede discernir para aceptar o rechazar. La verdad está entonces al nivel de la voluntad (86), y no de la inteligencia.

Anselmo nunca volverá a utilizar esta definición de la verdad. Pero esta definición será fundamental para estudiar las otras definiciones: la justicia es la rectitud de voluntad conservada por sí misma (DV 12; 194, 26) (87) y la libertad de elección es el poder de conservar la rectitud de voluntad por la misma rectitud (DLA 3; 212, 19-20) (88).

La rectitud es el fundamento del hombre (89). Porque si el hombre recibe y se recibe, su libertad es querer lo que Dios quiere que quiera (DLA), i.e. hacer lo correcto. Esa es su vida, es la finalidad de su vida: haz esto y vivirás (Lc 10, 28). Jesús repite esta frase después de hablar del mandamiento del amor. La rectitud es el fundamento del hombre y un fundamento del cual no se puede separar y que no puede recobrar por sí mismo cuando lo pierde. Por eso, es un milagro más grande devolver la rectitud al que la perdió que resucitar a un muerto (DLA 10). La rectitud es entonces parte fundamental del enigma.

2) Podemos comparar ahora los textos estudiados con las Oraciones (Or) y Meditaciones (Med) que Anselmo escribió en la misma época (90).

La Oración 7 tiene como finalidad "obtener el amor de María y el amor de Cristo" (7; 18, 3) (91). Por eso, el orante repite: "María, mi corazón quiere amarte, mi boca desea alabarte, mi mente desea venerarte" (L. 5-6) (92) porque busco tu protección. Así puede resumir la importancia de María para el ser humano: "Restrinjo demasiado tus méritos cuando en mí, hombre vil y sin importancia, enumero tus beneficios de los cuales el mundo goza cuando ama y, al gozar de ellos, proclama que son suyos" (L. 52-54) (93). Los méritos de María pasan todos al mundo. Esa es la fecundidad propia de María, fecundidad llena de amor (L. 55) porque da la

(84) Cf. también Conc III, 6; 270, 24.

(85) DV 12; 192, $6 \mathrm{ss}$.

(86) Cf. DV 4 citado en nota 78

(87) Iustitia igitur est rectitudo voluntatis propter se servata.

(88) Illa libertas arbitrii est potestas servandi rectitudinem voluntatis propter ipsam rectitudinem.

(89) A ese respecto, es fundamental el libro de R. POUCHET, La rectitudo chez St Anselme. Un itinéraire augustinien de l'âme à Dieu, Paris Etudes Augustiniennes, 1964.

(90) De la primera época son: Or $5 ; 6 ; 7 ; 8 ; 9 ; 10 ; 13 ; 14 ; 16$ y Med $1 ; 2$.

(91) Pro impetrando eius et Christi amore.

(92) Te vult cor meum amare, te cupit os meum laudare, te desiderat venerari mens mea

(93) Nimium contraho merita tua, cum in me homunculo vili singulariter recenseo beneficia tua, quae mundus amans gaudet, gaudens clamat esse sua. 
salvación: hace visible al Creador y Salvador. Por eso, María es "digna de amor cuando se la contempla y deleitable cuando se la ama" (L. 89-90) (94). Nada es más grande que María, fuera de Dios (L. 94) (95). Y Dios dio a María a su Hijo a quien amaba como a sí mismo (L. 95) para, de María, hacerse este mismo Hijo. Así el orante puede pedir que "el amor hacia ti esté siempre conmigo y la preocupación por mí esté siempre contigo" (L. 110-111) (96). Porque es "grande y digno de amor lo que veo nos acontece a través tuyo (L. 131) (97). Lo creo y lo amo, lo confieso y alabo (L. 135). María es nuestra Madre, Jesús es nuestro hermano, ¿con qué afecto debo amarlos? (L. 144).

La oración se dirige entonces a María y a su Hijo, nuestro hermano: "engordad mi alma y encendedla de vuestro amor" (L. 158) (98), "que mi corazón desfallezca por vuestro amor" (L. 158-159) (99); “que las entrañas de mi alma enmudezcan por el dulce fervor de vuestro amor" (L. 160) (100). "No soy digno de ser beatificado por vuestro amor como debería, pero no sois indignos de ser amados así y más todavía" (L. 164-165) (101). Se les pide entonces regalar no según los méritos del hombre, sino amar según su propia dignidad de madre y de hermano (L. 169). Es justo pedir este amor y justo exigirlo (L. 182). La consecuencia está clara: Todo lo que María y Jesús aman es justo y es su deseo que lo amemos (L. 185). "Entonces, buen Hijo por el amor con el cual amas a tu madre, te ruego que así como la amas verdaderamente y quieres sea amada, así me des amarla verdaderamente. Y tú, buena madre, por el amor con el cual amas a tu Hijo, te ruego que así como lo amas verdaderamente y quieres sea amada, así me obtengas (impetrare) amarlo verdaderamente" (L. 185-189) (102). Y retomando la petición inscrita en el título, puede gritar y preguntar: Madre de este que nos ama (L. 193: amator), “¿no querrás obtener (impetrare) su amor y el tuyo a quien lo reclama?” (L. 194-195) (103). Y puede terminar el orante pidiendo "que mi corazón os ame según es justo, os ame según le conviene a mi alma” (L. 196-197) (104).

La Oración 8 por primera vez, llama al santo, aquí Juan Bautista, amigo de Dios. La oración se dirige a Juan porque es amigo de Dios y se espera de él alguna gracia (L. 10) porque, a él, la gracia lo hizo amigo de Dios (L. 14). El orante se sabe pecador; sabe que Dios nuevamente formó en él una imagen suya digna de amor (L. 30) y él sobreimprimió otra digna de odio por causa del pecado. Por eso, el amigo puede intervenir, el que presentó al que quita el pecado del mundo (L. 94).

(94) Amabilis ad contemplandum, delectabilis ad amandum.

(95) Nihil nisi Deus maius Maria. Admiremos la osadía teológica que retoma el argumento del Proslogion.

(96) Amor tui semper sit mecum, et cura mei semper sit tecum.

(97) Quam magnum, quam amabile est quod video per te evenire nobis.

(98) Impinguate et succendite eam vestra dilectione.

(99) Vestro continuo amore langueat cor meum. Cita de Ct 2, 5.

(100) Viscera animae meae dulci fervore vestrae dilectionis exardescant.

(101) Non sum dignus qui sic debeam vestro amore beatificari, certe vos non estis indigni qui sic, immo plus debeatis amari.

(102) Ergo bone fili, rogo te per dilectionem qua diligis matrem tuam, ut sicut tu vere diligis et diligi vis eam: ita mihi des ut vere diligam eum. Bona mater, rogo te per dilectionem qua diligis filium tuum, ut sicut vere diligis et diligi vis eum: ita mihi impetres ut vere diligam eum.

(103) An tu non poteris aut non voles poscenti amorem eius et tuum impetrare?

(104) Amet vos sicut aequum est cor meum, diligat vos sicut sibi expedit anima mea. 
La Oración 9 a San Pedro recuerda que Cristo le preguntó a Pedro 3 veces si lo amaba $(9 ; 31,40)$ antes de confiarle el apacentar a sus ovejas. Y acota: "Ciertamente ama a la oveja quien examina así el amor del pastor antes de encomendárselas" (L. 41) (105). Por eso confía el orante en Pedro el apóstol amado (L. 88) para que obtenga misericordia de Dios.

La Oración 10 llama a Pablo, amigo de Dios $(10 ; 38,136)$ porque se hizo todo para todos $(1$ Co 9, 22) y así el orante puede confiar en él. Esta oración insiste en la importancia de una oración persistente porque Jesús y Pablo aman al que llora e insiste (L. 175) (106). Pablo es una madre afectuosa (L. 178) que se preocupa por sus hijos (107).

La Oración 13 es un llamado a San Esteban para que interceda ante su amigo omnipotente que es nuestro creador y Señor (13; 50, 13-14). Esteban es el querido de Dios (L. 52), el amigo querido (L. 65), el amigo (L. 66) y Cristo es el amante queridísimo (L. 61). En su perdón hacia los enemigos, Esteban arde de amor (L. 70), es como un panal de miel rebosante de amor (L. 72), y así da esperanza a los pecadores, sus amigos (L. 75). En la oración, cada personaje está bien definido: Cristo es misericordioso y creador, el orante es miserable y obra suya, Esteban es el amante amigo suyo (L. 64-65) (108).

La Oración 14 a San Nicolás empieza y termina presentando al orante como amigo del santo $(14 ; 56,24)$ porque así Dios no lo puede odiar y tendrá que escuchar su queja y no puede condenar al amigo del que intercede (L. 184). El orante está seguro que Dios escuchará la petición del santo porque es su amigo querido (dilectus dilector: L. 65-66). Se queja el orante que "el amor de lo terrestre apagó en él el placer de lo celeste" (L. 87) (109). Insiste ante Dios por los méritos de san Nicolás, querido tuyo (L. 167-190).

La Oración 16 a María Magdalena comienza meditando a Lc 7, 36-50, sobre todo el v. 47: "Sus muchos pecados le son perdonados porque amó mucho" (16; 64, 9) (110). María Magdalena es la amante elegida y la amada electora de Dios (L. 16) (111). Para ella "no es difícil obtener todo lo que quiere de tu Señor queridísimo y suavísimo y amigo tuyo" (L. 24-26) (112).

Para Anselmo, María Magdalena es la que lavó los pies de Jesús frente a sus calumniadores (Lc 7, 36-50), es la hermana de Marta (Lc 10, 42 s), fue criticada por Judas (Jn 12, 4 s) y lloró frente al sepulcro vacío (Jn 20,11) porque ardía de amor (L. 32) o mejor porque Cristo mismo la encendía siempre más de manera inefable y amigable (amicabiliter: L. 33). El mismo inspiraba este amor (L. 53). La oración continúa meditando las lágrimas de María buscando a Cristo (Jn 20): no ve al Señor su querido (L. 61). Por eso el amor tierno (L. 65) no puede soportar sus gemidos,

(105) Certe amator est ovis, qui ante commendationem sic discutit amorem pastoris.

(106) Cf. Lc 18, 1-8: la parábola del juez inicuo y de la viuda.

(107) Cf. Gal 4, 19; 1 T 2, 7.

(108) Ipse enim est misericors et creator meus, ego miser et opus eius, tu dilectus amicus eius.

(109) Amor terrestrium extinxit in me delectationem caelestium.

(110) Dimissa sunt peccata multa, quoniam dilexit multum.

(111) Electa dilectrix et dilecta electrix. Dilectrix, electrix: hapax en la obra anselmiana.

(112) Non erit enim tibi difficile, quidquid volueris obtinere a dilectissimo et suavissimo Domino et amico tuo. 
irrumpe la dulzura del amante (L. 66) y se da a conocer. Al decir el nombre de 'María' (Jn 20, 13), ella siente todo el amor (L. 70).

La oración termina con una invocación a Cristo que es la Verdad. "O Verdad, eres testigo que hago esto por amor de tu amor, deseo que tu amor arda en mí porque solo deseo amarte y lo que ordenes" (L. 79-81) (113). Se le pide que atienda a la oración a causa del amor y de los méritos de esta querida María (L. 84) y de su Madre María, que ayude el esfuerzo de este enamorado débil (amator: L. 87) "por el fervor de tu amor, dame alcanzar la contemplación eterna de tu gloria" (L. 87-88) (114).

Las Meditaciones utilizan poco las palabras afectivas. La Meditación 1 termina con una cita del Salmo 5, 12: "admíteme entre el número de tus elegidos para que te alabe y me gloríe entre todos los que aman tu nombre" (1; 79, 96-98) (115). En la Meditación 2, el orante llora su virginidad perdida. En su tristeza la llama la 'no amada' $(2 ; 80,20)$ y presenta su alma como una meretriz, una fornicadora que tomó la iniciativa de repudiar a Dios que la ama y la creó (L. 34), de abandonar al amante casto (L. 39).

Esta referencia a la verdad en la Or 16 nos ayuda a unir las Oraciones y Meditaciones (textos más afectivos) con los 3 textos anteriores (libros más racionales). La verdad no es algo, es alguien. Entonces buscar la Verdad, vivir la verdad, es relacionarse correctamente con esta persona. Por eso, la verdad se relaciona con la justicia y la libertad. Cuando hablo de 'relación correcta', pienso en la rectitud que es la nueva traducción del amor. El enigma del hombre se amplía.

Además, podemos decir que, porque las Oraciones son ejercicios más afectivos, reflejan mejor la vivencia y quizás el pensamiento del autor que no se siente sometido a un silogismo riguroso. En cada oración (116), Anselmo empieza declarando su bajeza como pecador para, luego, ponerse en las manos de Dios y de sus Santos. La vida del cristiano está en reconocer su realidad propia (es pecador) y la de los Santos (son amigos de Dios). La amistad, que hemos visto de gran importancia en la vida del monje, es la realidad escatológica de todo hombre. Esta amistad es otro nombre del 'cara a cara'. Pero los Santos no viven esta amistad con Dios de manera egoísta: la comparten con los hombres. Hay una relación estrecha entre la Iglesia triunfante y la Iglesia militante. La finalidad de toda oración es obtener (impetrare) algo del Santo o de Dios. Este verbo 'impetrare' tiene un sentido escatológico. Muestra una búsqueda, un dinamismo para obtener lo deseado y esto se logra solamente en la comunión perfecta con Dio que viven los Santos, es decir nuevamente el 'cara a cara' de la visión beatífica. Este verbo se utiliza exclusivamente en las Oraciones (117). El único empleo en los libros reflexivos está en el Cur Deus Homo (CDH), lo que le da un sentido cristológico. En CDH II, 16,

(113) Veritas, tu mihi testis es ... quia amore tui amoris hoc facio, amorem tuum in me accendere cupio, quia te solum et quod iubes desidero amare.

(114) Per fervorem tui amoris da mihi pertingere ad aeternam tuae gloriae contemplationem.

(115) Admitte me intra numerum electorum tuorum, ut cum illis te laudem ... et glorier in te inter omnes qui diligunt nomen tuum.

(116) Y era costumbre actuar así en la Edad Media: Es la tesis de J.-F COTTIER, o.c.

(117) CONCORDANCIA: Or $6 ; 15,16-17-7 ; 18,3.13 ; 24,148 ; 25,189.195-8 ; 29,102-103.103-10 ; 34$, $44.46 ; 41,224.284-285-12 ; 45,3 ; 46,27.29 .40 ; 47,80-14 ; 57,65-16 ; 65,19-17 ; 69,39.44-$ Med 3; 91,207 - CDH II, 16; 118, 15-16. 
Anselmo define la actividad salvadora de Cristo como el que permite el perdón de los pecados para los hombres de todo lugar y de todo tiempo. Cada creyente que quiere obtener el perdón será absuelto gracias a la obra del Salvador: ¡tanta fuerza tiene su acción! (118).

\section{PARTE III}

En una tercera etapa, veamos el Cur Deus Homo (CDH). Este libro tuvo una preparación en la Epistola de Incarnatione Verbi (Inc). Allí Anselmo unía amor y fe: el cristiano debe creer sin vacilación y amar viviendo su fe (Inc 1; 7, 1). Solo entonces puede buscar razones de su fe.

1) La finalidad del libro es mostrar que Cristo es el salvador. Esto significa que Cristo vuelve a poner al hombre en lo que es el propósito original de Dios. Desde el comienzo de la primera parte del Cur Deus Homo, Anselmo llama amable, es decir digna de amor, la solución de la pregunta ‘¿por qué Dios se hizo hombre?' y es digna de amor porque es útil y porque tiene una razón bella (I, 1; 48, 9). La utilidad debe buscarse en la vida moral (es útil para vivir). La belleza de la razón está en el gozo por descubrir algo y poder ayudar a otros al comunicarles lo descubierto (119). La razón siempre está invitada a explorar lo que dice la fe y así a acercarse a la visión beatífica (120).

El c. 3 presenta las objeciones de los infieles a la presentación de un Dios que se hace hombre. La primera objeción es que parece que ofendemos a Dios al describirlo como un ser que nace, sufre y muere en la cruz. Responde Anselmo meditando 1 Co 1, 25 (121): la necedad divina es más sabia que la sabiduría de los hombres, y la debilidad divina, más fuerte que la fuerza de los hombres. Es decir: no injuriamos a Dios, sino que alabamos su misericordia, porque estábamos irremediablemente perdidos y, por su amor (dilectionem) y ternura nos restauró $(3 ; 51,2)$. Anselmo une misericordia y dilección.

El c. 6 explica esta dilectio de Dios $(6 ; 53,2)$ : en todo lo que hizo para redimirnos, Dios mostró su amor (p. 54, 1). Pero los infieles persisten: podría habernos mostrado su amor salvando al hombre de otra manera (L. 17). Anselmo le da importancia a esta crítica y la retoma de distintas maneras: si pudo ser de otra manera, ¿cómo mostró su amor de esta? (p. 55, 2.3). Además, con los ángeles les mostró su amor sin soportar sufrimiento (L. 5). Todo el Cur Deus Homo es respues-

(118) Voy a ver el CDH en la tercera parte, pero era bueno anotar esto desde ahora. Acotemos también que la tercera Meditación (Med 3) que es un resumen del CDH termina con esta petición: soy tuyo por creación, que sea tuyo por el amor... de Ti tengo el desear, que de Ti tenga el obtener.

(119) En la Commendatio operis ad Urbanum Papam II (Com) que está puesta como otro prefacio al libro, ya había declarado que "cuando descubro algo que antes no había visto, lo abro con agrado a otros" (Com; 40, 15-16: et cum aliquid quod prius non videbam reperio, id aliis libenter aperio).

(120) La misma Commendatio invita a ver la inteligencia de las cosas como medio término entre la fe y la visión. Así todo progreso nos acerca a la visión beatífica (Com; 40, 7-12).

(121) Cf. Corbin, nota a, p. 309, in: CORBIN, Tomo III. 
ta a este problema: lo que Cristo padeció para salvarnos era realmente muestra de su amor por los hombres (122).

El c. 10 (como continuación del c. 9) explica varias citas bíblicas. A la cita de Jn 6, 44 (Nadie puede venir a mí, si el Padre que me ha enviado no lo atrae; y yo le resucitaré el último día), Anselmo añade el empuje a la atracción y explica que no se trata de un acto violento de Dios, sino de una "tenacidad libre y amada de la voluntad buena recibida" $(10 ; 65,7)(123)$. Es decir, no es un acto tiránico de Dios que estaría violentando la libertad y la obliga atrayendo o empujando, sino que se trata de una reacción libre y llena de amor del ser humano totalmente libre.

Para entender esta idea (que nos ayudará a profundizar la antropología de Anselmo), tenemos que profundizar esta última cita. En primer lugar, acotemos que estamos de lleno en las ideas (o en la teología) de Anselmo sobre la obediencia. He insistido en mi trabajo (124) sobre el hecho que entender la obediencia religiosa es indispensable para entender la teología de Anselmo. En este mismo párrafo, Anselmo nos da una definición de la obediencia: "la obediencia es simple y verdadera cuando la naturaleza racional conserva la voluntad recibida de Dios no por necesidad, sino libremente" (L. 17-19) (125). Anselmo insiste en sus libros sobre la recepción (accipere) y conservación (servare) de lo recibido. Aquí habla de la recepción de la voluntad buena: lo básico del ser creado es querer libremente lo que Dios quiere que él quiera. Esto es el fundamento de los 3 libros bíblicos ya estudiados (DV, DLA, DCD).

Pero además Anselmo habla aquí de tenacidad. Tenacitas es hapax en el corpus anselmiano. Solamente hay 3 empleos del adjetivo 'tenax'. En una carta a Lanfranco, arzobispo de Canterbury, Anselmo le da noticias de un monje, Osberno, que en su tiempo había sido un monje rebelde en Canterbury y que Lanfranco envió castigado a Bec. Anselmo le anuncia que Osberno ha engordado y "crece de manera laudable cada día y progresa en la ciencia a través de la instancia del estudio, de la serenidad de carácter y de la memoria tenaz" (Ep 39; 150, 38-39) (126). Buena manera de explicar los progresos de un ex rebelde es describir sus avances en todo sentido (127). ¿Qué significa la 'memoria tenaz' (tenacem memoriam)? Pienso que se trata de los ejercicios de memoria que acostumbraban hacer los estudiantes medievales. Podría traducirse por "la constancia en los ejercicios de memoria". En la Epistola de Incarnatione Verbi (Inc), Anselmo habla de 'falsedad tenaz' (tenaci falsitate: 1; 9, 19) para advertir sobre los peligros que acechan al cristiano que se arriesga en los vericuetos de la teología sin la solidez de la fe ni la fuerza moral suficiente. En el De Casu Diaboli, Anselmo vuelve varias veces sobre el porqué el ángel malo no fue firme cuando fue creado igual al ángel bueno. En el c. 24, se

(122) Los últimos empleos de diligere en esta primera parte son citas bíblicas: Mt 3, 17 (el Hijo amado) en 8; 60, 3-2 Co 9, 7 (Dios ama a quien da con alegría) en 16; 74, 17 - Gal 5, 6 (la fe opera por el amor) en $20 ; 87,31$.

(123) Acceptae bonae voluntatis spontanea et amata tenacitas.

(124) Palabras de Creación, Santiago 2004, especialmente en los cc. 1 y 15.

(125) Nam tunc est simplex et vera oboedientia, cum rationalis natura non necessitate, sed sponte servat voluntatem a Deo acceptam.

(126) Venerabiliter pinguescit, et scientiae profectu per studii instantiam et ingenii serenitatem tenacemque memoriam cotidie laudabiliter crescit.

(127) Osberno volverá a Canterbury como monje ejemplar. 
pregunta por qué no sabían ni el ángel bueno ni el malo que el ángel malo sería castigado. Para Anselmo, es muy importante este no saber, porque así la voluntad está totalmente libre y solo se entrega a Dios por Dios y no por otro motivo (128). Podemos entender entonces que para Anselmo, "la voluntad buena es tan tenaz que basta para evitar el pecado" (DCD 24; 271, 19-20) (129). No se trata de una voluntad tenaz y porfiada para luchar contra el pecado, sino una voluntad buena y sostenida. Anselmo llama voluntad buena o recta la que quiere lo que Dios quiere que quiera. Nuevamente estamos en la obediencia.

Así podemos volver a la tenacidad de la voluntad buena en el Cur Deus Homo (I, 10; 65, 7): la tenacidad libre y amada es entonces la voluntad buena, amorosa (llena de amor) y sostenida que permite al hombre entregar su voluntad y entregarse totalmente a Dios por el solo motivo de amar a Dios y por ningún otro motivo. Así explica Anselmo la entrega total del Hijo y su obediencia hasta la muerte (L. 15) (130). Esto permite también entender cómo el Padre 'quiso' la muerte de su Hijo. Cuando alguien quiere soportar una pena para así perfeccionar algo bueno, "no queremos ni amamos su pena, sino su voluntad" (L. 25) (131). Así el Padre "quiso que el Hijo soportase la muerte tan piadosamente y de manera tan útil aunque no amaba su pena" (L. 28-29) (132).

El c. 20 comienza una explicación de la satisfacción. Bosón, el discípulo, reconoce que la satisfacción es dar a Dios algo para honrarlo y esto se hace con temor y amor $(20 ; 86,28)$. Puede describir toda la vida monacal con sus sacrificios: eso es lo que ofrece a Dios para honrarlo. Para Anselmo, todo lo debemos a Dios (133). En esta vida, debemos llenarnos de amor (p. 87, 5) y de deseo de llegar a ser eso para lo cual fuimos creado. Para eso son útiles los sacrificios. Solamente merecemos tener lo que amamos y deseamos (L. 9). Pero hay que reconocer que todo fue recibido, y devolver es simplemente un deber. Es la obediencia: ¿qué dar a Dios que no le debamos? Bosón trata de salvarse citando a San Pablo: la fe que obra por la dilección nos salvará (L. 31) (134). Pero Anselmo recuerda el método autoimpuesto en este libro: no hablar de Cristo y proceder por la sola razón. Queda la pregunta: ¿qué devolver a Dios?, ¿cómo satisfacer?

La segunda parte del Cur Deus Homo comienza describiendo al ser humano. La finalidad de su creación es gozar de Dios y ser feliz. Para esto el hombre tiene el poder de discernir y esto significa odiar el mal y apartarse de él, "amar y elegir el

(128) Recordemos que "la justicia es la rectitud de voluntad conservada por ella misma" (DV 12; 194, 26) y que "la libertad de elección es el poder de conservar la rectitud de voluntad por ella misma" (DLA 3; 212, 19-20) (texto en notas 87-88). En estas definiciones, la preposición propter es importante. Propter significa una causalidad: para ser justo, hay que conservar la rectitud de voluntad por ella misma, a causa de ella misma y no por otra causa o razón. Así también para actuar libremente, el único causal es buscar solamente esta misma rectitud y no otra cosa.

(129) Tam tenax erat bona voluntas ut sufficeret ad cavendum peccatum.

(130) Cf. Flp 2, 8. Cf la definición de la obediencia supra.

(131) Non tamen volumus aut amamus poenam eius, sed voluntatem.

(132) Voluisse ut Filius mortem tam pie, tam utiliter sustineret, quamvis poenam eius non amaret.

(133) El 'deber' es fundamental para entender la teología de Anselmo. Cf. mi trabajo 'Palabras de creación', especialmente el cap. 15.

(134) Gal 5, 6: in fide christiana quae per dilectionem operatur. Recordemos que este texto de Gal 5, 6 ya fue citado en Mon 78; 85, 6 cuando Anselmo diferencia la fe viva de la fe muerta. 
bien y amar más y elegir un bien mayor" (II, 1; 97, 10-11) (135). Es evidente que el discernimiento es inútil y vano (136) si no ama o evita lo que discernió como malo (L. 13). Así ama y elige el Bien eminente por sobre todas las cosas (L. 15) y no por (propter) otra cosa sino por (propter) (137) este mismo Bien. Porque si ama por otra cosa, no ama al bien, sino esta otra cosa (L. 16). Eso es la justicia que va junto con lo razonable.

Ahora si fue hecho justo para elegir y amar el Bien eminente (L. 18), esto significa que busca alcanzar lo que ama y elige (L. 19) porque nuevamente si no alcanza lo que ama y elige (L. 20) fue creado en vano para amar y elegir (L. 21), porque ama y elige (L. 22) lo que nunca gozará. La consecuencia es lógica: la naturaleza razonable fue hecha para gozar de Dios y ser feliz. La finalidad es la felicidad con Dios o en Dios. Resaltemos aquí la unión de amare y eligere: la voluntad (amar) y la razón (elegir) se unen en el discernimiento que es el resumen de toda la vida y de todo el sentido de la vida del ser humano.

El c. 13 recordará lo mismo. Al describir a Cristo y buscar lo que asumió de nuestra naturaleza, acota Anselmo que asumió nuestras incomodidades (c. 12), pero no la ignorancia. En efecto, para amar algo, hay que conocerlo $(13 ; 112,28)$. Y "no habrá ningún bien que él no ame ni ignore" (L. 29) (138). Es decir: conocerá perfectamente el bien y lo discernirá del mal.

El c. 14 compara la muerte de Cristo y los pecados de los hombres. Es evidente que "la vida de Cristo es tan digna de amor como es buena" (14; 114, 26) (139), es decir: es más digna de amor que el pecado es digno de odio (L. 27). “¿Piensas que un bien tan grande y tan digno de amor puede ser suficiente para solventar lo que se debe por los pecados del mundo entero?" (L. 29-30) (140). La respuesta es: mucho más de lo pensable (plus in infinitum: L.31). Lo que quiere afirmar Anselmo es que una cosa buena es infinitamente superior a cualquier cosa mala. La acción de Cristo es por doquier infinitamente superior al pecado.

Todo lo anterior es una preparación para el c. 16. Anselmo presenta una parábola. En una ciudad todos pecaron contra el rey. Solo un inocente se presenta para salvar a sus conciudadanos. "Este tiene tanta gracia ante el rey que puede y tanta dilección hacia los culpables que quiere reconciliar a todos los que creen en su empresa por algún servicio que será muy placentero ante el rey mismo" (16; 118, 911) (141). El gesto se llevará a cabo el día fijado y tiene tanta fuerza (tanta vis: L. 22) que abarca a todos los hombres de todos los tiempos.

Este c. 16 es capital para entender el Cur Deus Homo y el pensamiento de Anselmo. Cristo obedeció hasta la muerte (Flp 2). Su ofrecimiento tiene tanta fuerza

(135) Amaret et eligeret bonum, atque magis bonum magis amaret et eligeret.

(136) El temor de que algo haya sido hecho 'en vano' es importante en este primer capítulo. FRUSTRA: p. 97, 7.8.11.13.17.21 - IN VANUM: p. 97, 12.

(137) Cf. nota 128.

(138) Nihil erit boni quod non amet, ita nullum bonum erit quod ignoret.

(139) Vita ista tantum amabilis quantum est bona.

(140) Putasne tantum bonum tam amabile posse sufficere ad solvendum, quod debetur pro peccatis totius mundi?

(141) Ille autem qui solus est innnocens, tantam apud regem habet gratiam ut possit, et tantam dilectionem erga reos ut velit omnes qui suo credent consilio reconciliare quodam servitio valde ipsi regi placituro. 
(tanta vis), tanta tenacidad amorosa porque es la entrega total y amorosa a la voluntad de Dios. Cristo recibe y se recibe: es su vida de Hijo. Esto da pie para entender la satisfacción según Anselmo. Para nosotros que todo lo debemos a Dios, la satisfacción es buscar querer lo que Dios quiere que queramos. Es aceptar recibir todo para gozar de Dios y ser feliz. El amar y elegir amar es la vida del hombre. El robo (142) de Adán es la actitud contraria a la actitud de Cristo. En la obediencia de Cristo empieza la solución del enigma del hombre porque nos abre a la visión beatífica.

2) Varios libros fueron escritos a continuación del Cur Deus Homo. El De Conceptu Virginali et de Originali Peccato (DCV) fue escrito para resolver problemas que dejó inconclusos el Cur Deus Homo. El principal problema es entender cómo una persona puede nacer sin el pecado original y estar incluida totalmente dentro del género humano. Notemos en este libro 2 empleos de affectus y 1 de affectio. En el c. 2, explica Anselmo la corrupción de la naturaleza desde Adán. Adán y Eva pecaron personalmente $(2 ; 141,9$ ss ) y así se encontraron debilitados y corrompidos. Su cuerpo está sometido a la corrupción y a los apetitos carnales. El alma también está infectada por los afectos carnales (L. 15), i.e. por los movimientos hacia la carne. En el c. 5 explica que el mal no es nada, como lo es la ceguera; solo es ausencia. Por eso es "fácil reconocer que la injusticia no tiene esencia alguna aunque la costumbre llame injusticia los afectos (movimientos) y actos de la voluntad injusta" (5; 146, 20-22) (143). Esto nos permite entender que la afección (affectio) es la inclinación del alma resultante del affectus y que esta afección se puede llamar también fruto de la voluntad $(4 ; 144,2)$.

Veamos ahora las palabras 'amar' y 'diligere'. El c. 18 describe a Cristo y a María: "Era decente que brillara en esta pureza de la cual mayor bajo Dios no se puede entender, aquella virgen a quien Dios Padre se disponía a dar a su único hijo engendrado igual a sí mismo y que amaba con todo su corazón como a sí mismo, de tal manera que sea por naturaleza el único y mismo hijo de Dios Padre y de la virgen" (18; 159, 17-20) (144). Admirable descripción de la Encarnación, de la Trinidad y de la importancia fundamental de María en el plan de Dios. Anselmo utiliza su argumento del Proslogion (mayor no se puede entender) que, aunque pone una cierta reducción (bajo Dios), expresa de manera admirable la grandeza de María. Si además colocamos a la Virgen frente a este Hijo a quien el 'Padre ama como a sí mismo', nos damos cuenta del gesto y del significado del amor de Dios: Dios entrega a su Hijo único para que llegue a ser Hijo suyo y de la Virgen. Dios comparte a su Hijo que ama como a sí mismo.

(142) Siguiendo a Flp 2, 6 (non rapinam arbitratus est esse se aequalem Deo: no estimó como presa (robo) el ser igual a Dios). Anselmo ve como un robo el deseo de Adán y Eva de hacerse semejantes a Dios en Gn 3, 5 (Inc 10). Tiene la misma idea en DCD 26 y 28.

(143) Ex his ergo facile cognoscitur quia iniustitia nullam habet essentiam, quamvis iniustae voluntatis affectus et actus, ... usus 'iniustitiam' vocet.

(144) Decens erat ut ea puritate, qua maior sub Deo nequit intelligi, virgo illa niteret, cui Deus Pater unicum Filium, quem de corde suo aequalem sibi genitum tamquam se ipsum diligebat, ita dar disponebat, ut naturaliter esset unus idemque communis Dei Patris et virginis Filius. 
El c. 24 resume lo que veremos en seguida con los sentidos: la justicia o injusticia está en la voluntad de aquel que ama o desprecia lo que debe o no debe $(24 ; 167,21)$.

El De Processione Spiritus Sancti (Proc) fue escrito después de la intervención de Anselmo en el Concilio de Bari (1098) y a petición de algunos obispos. Es un escrito circunstancial. Anselmo busca explicar la afirmación del Credo latino sobre el 'Filioque' y mostrar que los griegos se equivocan al despreciar a los latinos. El texto no emplea las palabras 'afectivas', excepto un solo empleo de 'amor' (145) y uno de caritas en el c. 1, es decir cuando todavía no ha entrado en el corazón del debate y está explicando el porqué del libro.

Como en muchos de sus libros, Anselmo empieza con gesto de humildad: muchos podrían hacerlo mejor que yo, pero muchos insistieron para que yo lo haga. Por eso, "no me atrevo a resisitr tanto por el amor debido a la verdad, como por su caridad (i.e. amor fraterno) y religiosa voluntad" (1; 177, 11-13) (146). La caritas, como lo hemos visto en otros libros, es el amor fraterno entre iguales, entre monjes por ejemplo o aquí entre obispos. ¿Qué significa 'el amor debido a la verdad'? Literalmente pro debito veritatis amore es 'el debido amor de la verdad'. Debere indica en la obras de Anselmo la respuesta del hombre a los dones de Dios. No se trata de lo debido como respuesta obligada o forzada para devolver un préstamo u obedecer a una ley. El 'deber' es una respuesta de amor a un don de amor. El amor debido es entonces la respuesta lógica del hombre al amor de Dios. Así la veritas (veritatis amore) puede ser entendida como el mismo Dios en cuanto cognoscible o por lo menos toda verdad que nace de Dios. Es evidente entonces que el amor fraterno (eorum caritas) unido al amor de la verdad (veritatis amore) es lo que debe impulsar al hombre (a todo hombre, a todo creyente, a todo teólogo) a buscar una profundización de su fe y a participarla a los demás. Es lo que impulsa a Anselmo a escribir (147).

En el mismo tiempo que escribía el De Processione, Anselmo escribió varias cartas a un obispo alemán, Galerano obispo de Nuremburg en Sajonia. Este obispo respaldaba la posición de los griegos. Además tenía posiciones fundamentalistas en su teología de los sacramentos. En su carta (W) parece confundir unidad e uniformidad. Habla de "una sola fe, un solo bautismo, una sola amiga, esposa y paloma de Cristo" (W 3; 233, 13-14) (148). Entonces. ¿por qué existe una diversidad de liturgias? Se queja que cada uno sienta a su manera $(1 ; 234,2)(149)$.

Entre la primera carta de Anselmo (AZ) y la segunda (SA), la atmósfera es muy distinta. En la primera carta, Anselmo regaña a Galerano por ser favorable al sucesor de Julio César, Nerón y Juliano el apóstata contra el sucesor de Pedro. Por eso, no puede saludarlo como amigo (AZ 0; 223, 6). En la segunda, el tono es más

(145) Si, en el Monologion, Anselmo definió al Espíritu Santo como el amor del Padre y del Hijo, parece extraño que en este libro no utilice la palabra 'amor'.

(146) Pro debito veritatis amore tum pro eorum caritate et religiosa voluntate non audeo resistere.

(147) Para confirmar esto, se puede leer el prólogo del Monologion (Mon) y la Commendatio operis (Com).

(148) Una est fides, unum baptisma, una Christi amica, sponsa et columba.

(149) Los otros empleos no se refieren al tema de la carta: Cristo mostró su gloria a los que lo amaban $(4 ; 236,24)$. Termina deseando que el Señor lo corone en la misericordia y ternura $(5 ; 238,6)$. 
comprensivo. Saluda a Galerano como "el Señor y amigo Galerano" (SA 0; 239, 2) (150), le presenta "afecto de amor" (L. 4) (151) porque tiene "la amistad y familiaridad del Señor Papa Pascal de tal manera que me es lícito saludar amablemente vuestra santidad" (L. 7-8) (152). Anselmo acepta los elogios recibidos de la buena voluntad y no se queda en menos: "solemos sentir a los que amamos mejor que ellos mismos se lo merecen. Sin embargo, mi corazón no se gloría de la alabanza que no siente, sino que se alegra y da gracias por el amor que siempre debe ser amado" (L. 12-15) (153).

También precisa el porqué de las diferencias en la liturgia. Ya los Padres afirmaban que si se conserva la unidad en el amor fraterno (caritas), entonces la diversidad de costumbres no es obstáculo para la fe $(1 ; 240,9)$. La diversidad proviene de la diversidad de los sentidos humanos (L. 11). La caridad y los sentidos en lugar de dividir, son expresión de unidad.

3) Respecto al De Concordia Praescientiae et Praedestinationis et Gratiae Dei cum Libero Arbitrio (Conc) no hay indicaciones que nos expliquen cuándo y por qué lo escribió Anselmo. Ciertamente fue el resultado de un largo trabajo. Este quería profundizar temas ya tocados en obras anteriores, especialmente en el De Veritate y el De Libertate Arbitrii que cita explícitamente. El tema del libre albedrío y de su relación (concordia) con otros temas (predestinación y gracia) es un problema que ha interesado a todas las generaciones de cristianos. Por eso parece normal que Anselmo nos dé su aporte.

El libro se divide en 3 partes según los 3 temas anunciados. En la primera parte del libro, acotemos una frase de Anselmo que podría servir de proverbio: "Alguien tiene en el corazón de tener la verdad porque entiende que es recto amar la verdad" (I, 6; 257, 8-9) (154). El deseo de tener la verdad ya es rectitud y justicia. Si alguien quiere forzar a tal hombre a mentir, este hombre sigue siendo libre y capaz de juicio porque sabe que la rectitud siempre debe ser conservada por el solo amor a la rectitud (L. 14). Anselmo está aplicando la definición de la justicia descubierta en el De Veritate (155). Allí insistía ya en el propter se servata que recuerda al final de este c. (p. 257, 25-27). Según M. Corbin, el hombre al que se quiere forzar a mentir es Cristo mismo. Este sigue firme en la verdad hasta la muerte (156).

En la tercera parte, Anselmo recuerda la misma definición de la justicia (III, 2; $265,15)$ y vuelve a insistir en que "el que conserva la justicia solo por otra cosa, no ama a la justicia, sino esta otra cosa por la cual la conserva” (L. 15-17) (157).

(150) Domino et amico Waleramno.

(151) Dilectionis affectum.

(152) Domini Papae Pascalis habetis et familiaritatem, ut iam mihi liceat vestram amicabiliter salutare sanctitatem.

(153) Solemus enim saepe sentire meliora de iis quos diligimus, quam ipsi mereantur, De laude igitur quae ad me non pertinet, cor meum non gloriatur, sed de dilectione quae semper amanda est, gratias agendo laetatur.

(154) Habet aliquis in corde ut veritatem teneat, quia intelligit rectum esse amare veritatem.

(155) Cf. DV 12; 194, 26: Iustitia igitur est rectitudo voluntatis propter se servata.

(156) Nota a, p. 181 in: CORBIN Tomo V. El mismo ejemplo fue tomado en DLA 5.

(157) Qui enim solum propter aliud illam servat, non eam diligit, sed illud propter quod illam servat. 
Acotemos también en esta tercera parte una cita del Salmo 34, 13 para mostrar la importancia del libre albedrío y su supuesta independencia de la gracia: “Cuál es el hombre que quiere la vida, ama ver días buenos?" (III, 1; 263, 21-22) (158). Y una reflexión sobre la creación: "Dios no hizo a la naturaleza miserable sin culpa precedente. La creó para entenderlo y amarlo" (III, 13; 286, 3-5) (159). Así puede recordar la bondad de la creación, la unión de Adán con Dios y la pérdida de la bondad por el pecado.

4) Podemos estudiar ahora el segundo bloque de Oraciones y Meditaciones. Desde el prólogo, Anselmo nos advierte que las Oraciones y Meditaciones "fueron publicadas para despertar la mente del lector hacia el amor o temor de Dios, o sea para el examen de sí mismo" (prol; 3, 2-4) (160). Acotemos simplemente que Anselmo pone al mismo plano el amor de Dios, el temor de Dios y la mirada sobre sí mismo. Según lo que ya hemos visto anteriormente, podemos entender la finalidad de estas oraciones: se trata de convencerse de lo profundo del pecado en el hombre y de la indispensable misericordia de Dios. El gritar hacia Dios para tratar de 'obligarlo' a dar su perdón y su gracia es parte de la finalidad de estas oraciones. Esto da la pauta para orar y para estudiar estas oraciones.

En la Oración 1, el orante, con frases recortadas, pide "creer, esperar, amar y vivir lo que tú sabes y quieres, cuanto y como tú sabes y quieres" (1; 5, 6-7) (161). Están las 3 virtudes teologales presentes "para amarte, orarte, alabarte y meditarte" (L. 8-9) (162). "Dame el conocimiento de tus mandatos, el amor profundo, el deleite, la facilidad y la facultad de cumplirlos" (L. 10-11) (163).

La Oración 2 se titula: "Oración a Cristo cuando la mente quiere ser encendida de su amor" (2; 6, 2-3) (164). Se trata de enfervorizarse (fervere). El orante se queja: "aunque todavía no merezco amarte como debería, sin embargo deseo amarte tanto como debo" (L. 12-13) (165). Recordemos que, en Anselmo, el deber no es una obligación o deber moral, sino un deber creación (pre-moral). Ser deudor (L. 12-13) o deber (L. 13) significa cumplir con la finalidad de la creación, es vivir eso para lo cual Dios nos creó. Por eso, la frase empieza con un vocativo: "Vida mía, finalidad de mi intención" (L. 12) (166). El orante puede insistir: 'amarte es un bien' (L. 16) y la petición es de ‘amarte tanto como me lo ordenes' (L. 17). Eso es el bien, eso es la finalidad de la vida de la creatura: merecer amar a Cristo, yo que no tengo mérito (L. 20). El hombre es tibio y pide convertir este sopor en amor fervien-

(158) Quis est homo qui vult vitam, diligit dies videre bonos? (tradicción de la BJ: ¿Quién es el hombre que apetece la vida, deseoso de días para gozar de bienes?).

(159) Non autem fecit Deus sine praecedente culpa ratinalem naturam miseram, quam ad intelligendum et amandum se creavit.

(160) Ad excitandam legentis mentem ad Dei amorem vel timorem, seu ad suimet discussionem editae sunt.

(161) Credere, sperare, amare, vivere quod et quantum et ut scis et vis.

(162) Ad te amandum, orandum, laudandum, meditandum.

(163) Mandatorum tuorum notitiam, dilectionem, delectationem, facilitatem et effectum

(164) Oratio ad Christum cum mens vult eius amore fervere.

(165) Etsi nondum merui te tantum quantum debitor sum amare, utique saltem desidero te tantum quantum debeo amare.

(166) Vita mea, finis intentionis meae. 
te (L. 21), encender el amor hacia él (L. 23). Se encuentra como un hombre alejado de su padre que abraza la cara amada (L. 32). Toda la oración muestra esta búsqueda: ¿dónde ir? Buscar? ¿Quién anunciará al amado que desfallezco de amor? (L. 7374) (167): solamente Cristo, el que ama a los hombres y es compasivo (L. 80) (168).

En la Oración 4 a la santa Cruz, acotemos que la cruz es digna de ser amada (4; 11, 8: amabilis) y que ella aleja del infierno y da la herencia del reino. Por eso, ella es la finalidad de nuestra vida si damos gracias, amamos y vivimos en ella (L. 48).

Juan es el apóstol más amado de Dios $(11 ; 42,4)$, el que Dios ama de una manera particular entre sus amados (L. 5). Lo ama tanto que "este amor sobreeminente es el signo propio para reconocerlo entre los apóstoles" (L. 6) (169). Por eso se atreve el orante: "A ti, o bienaventurado, tan amigo, tan amado de Dios, a ti suplicante acude este hombre vil, reo de Dios, para que a través de un intercesor tan querido evite sobre sí la inminente ira de Dios (L. 9-11) (170). A Juan el amado (L. 21-22) se le suplica porque el pecado va contra el que lo ama (dilector tuus: L. 22) y como consecuencia el pecador merece el odio suyo. "Cualquiera que comete un crimen contra Dios es digno del odio de los amigos de Dios; y no solo de sus amigos, sino también de sí mismo y de toda la creación" (L. 25-26) (171). El alma perdió el amor de Dios (L. 30) por culpa del pecado. Frente a Juan, el querido de Dios (L. 37), se siente amiga del siglo (L. 38) y entonces enemiga de Dios. Solo le queda recurrir a los amigos de Dios (L. 47) para obtener misericordia. Por eso se acerca a Juan a quien Jesús quería (L. 51) para pedir en nombre de este mutuo amor (L. 52) de dar a conocer su ayuda. Si es el discípulo a quien Jesús quería (L. 53), que el pecador sea aquel hacia quien Jesús sea indulgente. Acepta el pecador que Juan, el querido de Dios (L. 56), esté enojado con aquel que peca contra el Dios que lo quiere (L. 57), pero sabe que el Señor se apacigua por la intercesión de un amigo (L. 58). Juan fue gratificado de tanto amor de parte de Dios (L. 59), por eso se le pide reconciliar al pecador con su Dios. Para él, el querido de Dios, su intervención no va contra este amor (L. 60). "Amigo de Dios, no pienses que es enemigo de Dios a tuyo este que ama y cree tanto como puede y confiesa que Dios es tu amigo" (L. 63-64) (172). El deseo es de amar el gran amor que Dios le concedió a Juan (L. 65). Así se pide a Juan "a causa de aquel que te ama" (L. 67) (173) que actúe porque "quiere de verdad la obra de Cristo y la confesión de su nombre bendito" (L. 69-70) (174). La oración termina expresando a Jesús, el que quiere a Juan (dilector: L. 72), para que extienda el nombre de su querido entre el pecador y la sentencia (L. 74). "Por este bienaventurada dilección, perdona al que busca su protección" (L. 75-76)

(167) Quis nuntiabit dilecto quia amore langueo? (Ct 2, 5)

(168) Amator hominum benignissime.

(169) Supereminens dilectio sit tibi proprium signum inter eos.

(170) Ad te, o beate, tam amice, tam amate Dei, ad te exorandum accedit homuncio iste reus Dei, ut per tam dilectum intercessorem vitet imminentem sibi iram Dei.

(171) Criminosus Dei digne odiosus est amicis Dei. Nec solum amicis eius, sed certe et sibimet et omni creaturae eius.

(172) Amice Dei, ne deputes illum Dei vel tuum esse inimicum, qui quantum potest amando credit et confitetur Deum tuum esse amicum.

(173) Propter ipsum amatorem tuum.

(174) Vere diligis opus eius et confessionem benedicti nominis eius. 
(175). Porque el Señor no puede condenar a quien ora por el nombre de su querido (L. 77). “¿Bajo qué techo protegerse si se es golpeado bajo el nombre de tu querido? ¿Dónde refugiarse si hay peligro bajo tu querido?” (L. 77-79) (176). Hacia este querido huye el pecador (L. 80) para asegurarse que el pecado no tenga más poder que el amor del Redentor (L. 82). Que el discípulo que Cristo quiso con más familiaridad sea la causa de la salvación (L. 86).

La Oración 12 también se dedica a Juan Evangelista "para de él obtener el amor de Dios y del prójimo" $(13 ; 45,3)(177)$. A Juan se le presenta como uno de los grandes apóstoles, "Uno de los más ricos en amor por el cual Dios quiere y es querido y el más rico de ellos por el amor por el cual Dios quiere" (L. 5-6) (178). Por eso se le pide a él, rico amigo de Dios (L. 12), que presente el alma del pecador ante este Dios que los ama (dilector: L. 13). El orante se presenta ante él, el querido de Cristo (L. 16) (179) porque se sabe pobre de este doble amor (L. 17): "quiere a Dios muy por debajo de lo que debe y es querido por Dios mucho menos de lo que necesita" (L. 18-19) (180). No se trata de olvidar el amor de Dios a favor de los hombres (L. 22), sino de proclamar su pobreza "hasta no ser saciado de este doble amor" (L. 23) (181). Para lograr este objetivo, no bastan las súplicas de un pecador menos querido (L. 27), también se necesita los méritos del que te quiere y que tú quieres (dilectus dilector: L. 28).

Confiesa el orante que no es digno de ser amado (L. 32), pero que Dios no es indigno de que lo ame (L. 33). Por eso se proclama esclavo de su amigo (L. 39) y ruega a Juan, el querido de Jesús (L. 38) para que "a causa del nombre de su Señor que te ama, obtengas de él el mutuo amor" (L. 39-40) (182), es decir de ser querido por él para quererlo de una manera digna (L. 40-41). "Ciertamente, querido de Dios, si él nos quiere por causa tuya, tú extiendes la misericordia hacia nosotros; y si nosotros lo queremos por ti, tú le das la gracia. Ciertamente, Señor, si lo vuelcas a amarnos, haces de nosotros para ti los deudores de algo tan grande, y si nos enciendes a amarlo, te haces para él el que devuelve lo adeudado" (L. 41-45) (183). Es decir, el esfuerzo para que Dios ame más no lo perjudica y si muchos más lo aman, es retribución normal (L. 45-46).

Juan es el discípulo amado de la ternura (L. 51), ¿cómo podría olvidar a quien está necesitado? Si así lo quiere, su intercesión tiene tanto valor a los ojos de Dios que lo quiere (dilector: L. 59) que después de perdonar los pecados transformará al

(175) Per illam beatam dilectionem parce quaerenti eius tuitionem.

(176) Sub quo tegmine protegitur, si sub nomine dilecti tui percutitur? Ubi est refugium, si sub dilecto tuo est periculum?

(177) Título: pro impetranda dilectione Dei et proximi.

(178) Unus... ditissimorum dilectione qua diligit et qua diligitur Deus, et ditissimus eorum dilectione qua diligit Deus.

(179) Varias veces en la Oración, Juan está descrito por un adjetivo de amor: dilecte Domini nostri (L. 16), dilecte Iesu Christi (L. 38), dilecte Dei (L. 41), dilectissime discipule pietatis (L. 51), dilecte eius (L. 82), dilecte dilector (L. 86). Además, amor Dei (L. 81).

(180) Valde infra quam debet diligit Deum et multo minus quam eget diligitur a Deo.

(181) Donec satietur utraque tua dilectione.

(182) Propter nomen Domini sui, dilectoris tui, impetres illi mutuam dilectionem Dei.

(183) Certe namque, dilecte Dei, si ipse diligit nos propter te, misericordiam nobis impendis; et si nos diligimus illum per te, gratiam illi rependis. Certe, Domine, si illum convertis ad nos amandum, facis nos tibi tanti debitores; et si nos accendis ad illum amandum, facis te illi debiti redditorem. 
pecador por su amor en amante suyo (amator: L. 60). "Entonces, beato Juan, haz que quien te quiere, me quiera también por esta amplitud de caridad" (L. 61-62) (184). "Por la fuerza del amor que le debes, haz que liberes también mi amor con el tuyo" (L. 63-64) (185). "Si todos los que por ti aman a Dios tu amante no pueden corresponderle" (L. 67-68) (186), no dejes de lado al que suplica. Enciende su amor si se vuelve tibio (L. 69).

Entonces la oración se dirige a Jesús y a Juan con fuerza y originalidad: es que el amor inventa cosas para extorsionar amor (L. 74) porque el amor es fuerza del amor de Dios (L. 75). Hay seguridad que ambos quieren al pecador (L. 76). Así Jesús, “¿cómo pruebas tú que amas y cómo pruebo yo a alguien que lo amas si no me das ni de ser amado por ti ni de amarte? (L. 77-78) (187). Quizás es exceso, pero el amor empuja a hablar así (L. 81). Y el orante encierra a Jesús y a Juan en un chantaje de amor: "Tú, Dios, y tú, su querido, no se quieran solo a ustedes; también ámennos a nosotros los miserables" (L. 82-83) (188). Por eso, se pide a Juan, el amado amante de Dios (dilectus dilector Dei: L. 86), el que está asegurado del amor mutuo de Dios (L. 87), sea benigno para con el pobre pecador que mendiga este mismo amor mutuo (L. 88), es decir, querer a Dios y que querido por él (L. 97).

Entonces puede concluir la oración: espera, alégrate y ama, alma mía (L. 125), tu oración ha sido escuchada. "O bondad, o ternura, o amor. ¡Cuánto te muestra que te ama y cuánto te inflama para que lo ames!” (L. 128-129) (189). "Corazón mío y carne mía, exultan en él y quiéranlo. ¡Que todo lo que está dentro de mí lo bendiga!" (L. 131-132) (190).

De la Oración 15 solo acotemos que san Benito es querido de Dios (15; 63, $50)$, conductor y maestro del monje. La oración insiste en méritos e intercesiones. La Oración 17 insiste en que los santos son amigos de Dios $(17 ; 68,5)$ y que se le pide a Dios por los méritos de estos amigos (L. 36).

La Oración 18 se dedica a favor de los amigos $(18 ; 71,2)(191)$. En efecto, Cristo mismo hizo caridad a los enemigos y prescribió amar a los amigos (L. 8). El precepto es de amarse unos a otros (L. 17) y Cristo es el primer amigo (L. 18). "Tú sabes, Señor, que amo el amor que ordenas, quiero el amor, deseo la caridad" (L. 19-20) (192). La petición es entonces pedir clemencia para vivir "amando a todo hombre en ti y por causa tuya" (L. 23) (193), especialmente aquellos "de quienes tu amo imprimió amor en mi corazón (L.25-26) (194). Por eso pide, ora por los amigos (L. 28): es tu mandamiento, pero el amor mismo lo desea (L. 32). Entonces, "te pido por estos que me aman por tu causa y que amo en ti" (L. 37-38) (195) y por aquellos

(184) Ergo, beate Iohannes, fac ut qui te diligit, me quoque diligat per illam caritatis latitudinem.

(185) Fac per vicem dilectionis quam illi debes, ut meam quoque dilectionem cum tua illi solvas.

(186) Si ergo quotquot Deum amatorem tuum per te diligant.

(187) Iesu, unde tu mihi, aut ego cuiquam probo quia amas illum, si nec amari a te nec amare te das.

(188) Ergo, o tu Deus et tu dilecte eius, nolite vos diligere solis vobis beatis, sed et nos miseris.

(189) O bonitas, o pietas, o amor! Ecce quantum tibi ostendit quia te diligt, et quantum te accendit ut illum diligas!

(190) Cor meum et caro mea (Sal 83,3), exultate in illum et diligite illum, et omnia quae intra me sunt (Sal 102, 1) benedicite illum, amen.

(191) Título: oratio pro amicis.

(192) Tu scis, Domine, quia dilectionem quam iubes amo, amorem diligo, caritatem concupisco.

(193) Diligens omnem hominem in te et propter te.

(194) Quorum dilectionem... cordi meo impressit amot tuus. 
que me aman y que yo amo con más sinceridad (L. 38). Amalos (L. 40) "tú que eres la fuente del amor y que prescribes y me das de amarlos" (L. 41) (196). Amalos, no por mí, sino por ti (L. 44) y haz que te amen (L. 45).

La Oración 19 es oración por los enemigos. El orante desea que Cristo sea propicio a los amigos $(19 ; 73,3)$ y recuerda que Jesús mismo oró por su discípulo querido: quien no ama permanece en la muerte (L. 21) (197). Por eso el amor de los enemigos es importante. Tal es la venganza que se pide: "que te amemos y nos amemos unos a otros según lo quieres y nos es conveniente a nosotros" (L. 32-33) (198). Se pide al Señor que llene este movimiento de amor (L. 44) para saciar el alma y que sea amor de amigos y enemigos (L. 51).

La Meditación 3 desarrolla más. Desde el comienzo, el orante habla a su alma para que se dé cuenta de lo que es la redención. No se trata solo de reflexionar, sino de gustar $(3 ; 84,8)$, de comer y degustar todo lo que significa la redención (L. 8.9). Por eso le incita a despertar y encenderse en el amor del Salvador (L. 9), a amarlo y gozar de El (L.11) porque Cristo es el buen Samaritano, el amigo que salva y libera (L. 14). Debe amar la tierna voluntad del Salvador (L. 147). Por eso, pide considerar de cuánto amor es digno (L. 151) y cuánto debe a su amor (L. 152). Hay en esta Meditación una búsqueda de cómo unir conocimiento (intelecto) y amor (voluntad) (L. 186), porque no basta conocer y gustar; la búsqueda es de gustar por el amor (L. 196): "que sienta por el efecto lo que siento por el entendimiento" (L. 197) (199). Sabe el orante que debe todo al amor de Cristo (L. 194) y le pide ser atraído hacia su amor (L. 199): "todo lo que soy es tuyo por creación, hazlo tuyo por dilección" (L. 199-200) (200). La oración termina mostrando el deseo de amor meditando el Cantar de los Cantares (especialmente Ct 2, 5 y 3, 4).

\section{CONCLUSIÓN}

El recorrido por todas las obras de Anselmo ha probado con creces que este es un teólogo afectivo y especulativo: su pensamiento especulativo es fruto de su experiencia vivida (201). Anselmo se interesa por Dios (es ante todo un teólogo) y para expresar sus ideas teológicas debe interesarse por el hombre. Presentar y quizás esclarecer el enigma del hombre le es fundamental para expresar su misión teológica y lo es también para nosotros si queremos entender su pensamiento teológico (202).

(195) Pro his qui me diligunt propter te et quos ego diligo in te.

(196) Tu fons dilectionis, qui praecipis et das mihi ut diligam eos.

(197) Qui non diligit manet in morte: 1 Jn 3, 14.

(198) Ut te et invicem, sicut vis et nobis expedit, diligamus.

(199) Sentiam per effectum quod sentio per intellectum.

(200) Totum quod sum tuum est conditione; fac totum tuum dilectione.

(201) CATTIN Y., L'amour exilé. Saint Anselmo et Saint Bernard, Collectanea Cisterciensia 1990, pp. 171-173.

(202) No he presentado la antropología de Anselmo porque no tiene una manera única de expesar sus ideas. A veces habla de cuerpo y alma, otras de corazón, pensamiento y alma y otras de cuerpo animal y cuerpo espiritual. Cf. GILBERT P., Entrer dans la joie: Proslogion XXIV-XXVI, in: VIOLA C. - van FLETEREN F. (Eds.), Saint Anselm, a thinker for yesterday and today, Lewiston NY, Ed. Mellen Press 2002, pp. 232-233. 
El amor está presente en todo el pensamiento de Anselmo, sea el amor divino o reflejo de Dios (amor, amare), sea el amor de los bienes deliciosos o de amistad (dilectio, diligere (203)), sea el amor que asiste a los hermanos (caritas). Si Dios es amor (Mon - $1 \mathrm{Jn}$ ), es lógico que el hombre, imagen de Dios viva del amor, sea amor y comparta ese amor. El amor es entonces el punto de partida y la solución del enigma.

Aun los libros que no hablan de amor (DV, DLA, DCD) se refieren a Dios como Verdad y a la vida del hombre como rectitud. Esta rectitud perdida por el pecado solo se recupera por un milagro mayor al de la resurrección de un muerto (DLA 10). Esta rectitud se nos devuelve porque el Hijo se entregó por nosotros: tanta fuerza tiene su gesto, tanta fuerza tiene el amor. En estos libros el enigma se juega en la dialéctica de comprensión (la Verdad) y de voluntad (liberación) (204): el hombre debe querer lo que Dios quiere que quiera; el hombre debe recibir de Dios todo su ser. La obediencia, que Anselmo entiende como obediencia monástica, es la única manera de vivir porque es vivir como vivió el Hijo. El enigma del hombre es entonces la vera comprensión del verdadero hombre, Cristo.

Partimos de la cita de 1 Co 13, 12 en el Monologion y en San Pablo. Hemos visto que, para Anselmo, el enigma tiene siempre 2 enfoques: uno escatológico y otro que nace del amor, reflejo del amor de Dios. Estos 2 aspectos se funden: el amor es imagen del Dios Amor, es decir es vida divina en nosotros y preparación de la vida bienaventurada. Además, el amor o amistad, sea con seres humanos, sea con los Santos, es prefiguración y preparación de la vida del cielo. Tenemos que llegar entonces a la cita de 1 Jn 4, 7-8: amar es conocer a Dios y vivir como sus hijos. El conocimiento no es algo intelectual, sino amoroso. Esto significa que el hombre expresa su realidad (su propio enigma) en términos de relación y relación significa protagonismo (historia) y deseo (finalidad). Además el hombre sabe que él no creó esta relación (205). Dios nos amó primero (1 Jn 4, 10.19).

Por eso, el enigma llama al 'cara a cara' escatológico. Los seres humanos hemos desarrollado la vista más que otro sentido (206). Ver una cosa es apropiarse de ella (207). Entonces, el 'cara a cara' al que estamos llamados es apropiase del ser visto y amado, Dios. Ya no se trata de un espejo que refleja malamente, es transformarse: ustedes serán como dioses $(\mathrm{Gn} 3,5)$, pero no a la manera de Adán que robó. Estamos invitados a recibir esta divinización nuestra en primer lugar a través de la obediencia de Cristo y de la nuestra: el punto de partida del conocimiento es la obediencia amorosa con Cristo, en Cristo y como Cristo. Por eso, estamos invitados, no a dejar que la alegría nos impregne, sino a entrar en la alegría (Pr 26 - Mt 25, 21.23) (208).

El Proslogion es ciertamente el libro más representativo de Anselmo y el argumento único del c. 2 llena todo el libro. Sin embargo, no utiliza el verbo amare;

(203) GILBERT P., o.c., pp. 236-237.

(204) Recodemos la definición de la libertad de elección en nota 88 .

(205) CATTIN Y., o.c., pp. 178-179.

(206) Además de ver, tratamos de 'entre-ver', de 'pre-ver', etc. En latín, 'parecer' es 'ser visto' (Videri).

(207) CATTIN Y., o.c., p. 274

(208) CATTIN Y., o.c., p. 178. GILBERT P., o.c., p. 229. 
además parece no identificar la presencia de Cristo (209) aunque está explícitamente expresado en el último capítulo. No se puede olvidar que el argumento del c. 2 es un argumento escatológico y cristológico (210) y está retomado de diversas maneras en el Cur Deus Homo, libro cristológico por excelencia (211). Los últimos capítulos del Proslogion reflejan el fin de la búsqueda de sentido. En c. 23, Anselmo utiliza Lc 10, 42 (Una sola cosa es necesaria: Pr 23; 117, 20) y presenta este Bien único necesario: Cristo. Este Bien es mayor a todos los bienes (c. 24), retribuye (c. 25) hasta lo máximo (c. 26). Entrar en la alegría es hacerse hijos con el Hijo. Nuevamente, la obediencia es la única manera de prepararse dignamente para el encuentro con Dios. Por eso, Anselmo explica que la vida monástica es eso de lo cual "no puede haber nada mayor" (212).

El amor es la recompensa lógica del amor. Esto no significa que el amor busque recompensa, sino más bien lo contrario. Jesús jamás buscó recompensa alguna. ¿Qué podía recibir como recompensa aquel que es más grande que todo y que lo abarca todo? (CDH II, 19) (213). Jesús aprendió a obedecer (Hb 5, 8; Jn 4, 34; 5, 19) y porque obedece es libre y recibe el nombre sobre todo nombre (Flp 2, 9) y nos lo da a conocer (Ef 3, 19). En Cristo, en su vida y en su entrega obediente, hay sobreabundancia de dones (Or 14). Hay tanta abundancia que nos hace coherederos de su reino $(\mathrm{Rm} 8,17)$. Podemos extrañarnos que Anselmo no haya desarrollado un pensamiento eclesiológico o político, pero su posición de teólogo monástico, su sentido de la cristología, su amor como solución del enigma y su sentido de la escatología nos darían una base para iniciar un estudio eclesiológico y político.

¿Qué podemos devolver a Dios por tantos bienes? Nada, porque Dios no necesita algo que podamos ofrecerle. Entonces nos da como mandamiento devolver este amor suyo a los hombres (Jn 15, 17; 1 Jn 3, 16) (214). Esta es la satisfacción que pide a los hombres (Or 19; 74, 33-34). Esta es la venganza: amar al enemigo (215). Anselmo no busca una reconciliación del pecador con Dios a través de acciones calificables, sino una unión real interna, una alianza de libertades tal que el hombre pueda ‘enderezarse y levantarse por sí mismo' (CDH II, 8; 103, 9) (216).

En resumen, la solución del enigma es entonces la entrega total de Cristo por nosotros y la entrega total de nuestra vida en Cristo. Es la kenosis del Hijo, aceptada por el hombre, recibida y vivida por el hombre. La experiencia fundante de Anselmo es su experiencia de Cristo. Lo que él pide es que esta misma experiencia sea

(209) GILBERT P., o.c., p. 231.

(210) Cf. mi trabajo: Palabras de creación... o.c., p. 74.

(211) El argumento de Pr 2 ayuda a entender mejor el CDH: es la tesis que el Padre M. Corbin presenta en varios trabajos. El ejemplo más claro de CDH II, 20. Cf. entre otros, CORBIN M., Prière et raison de la foi, Paris Cerf 1992, passim. Id., L'intercession du Fils, in: VIOLA C. - van FLETEREN F. (Eds.), o.c., pp. 245-283.

(212) Ep. 121, 39: quo maius habere non potest. Cf. también la Ep. 120 citada en nota 72.

(213) CORBIN M., L'intercession du Fils, o.c., p. 249.

(214) Id., p. 256.

(215) Id., pp. 269-27. En la edición francesa de las Orationes (Tomo V, p. 397, nota b), el P. Corbin une la comprensión de la satisfacción con Mt 5, 48: ser perfectos en el amor, "car seul l'amour à la manière de Dieu peut plaire à Dieu".

(216) GILBERT P., Violence et liberté dans le Cur Deus Homo, in: GILBERT P. - KOHLENBERGER H. - SAlMANN E. (Eds.), Cur Deus Homo, Roma Pontificio Ateneo S. Anselmo 1999, pp. 683-684. 
nuestra (217). Recordemos Jn 8, 32: el Hijo es la Verdad (DV) y la Verdad nos hará libres $(\mathrm{CDH})$.

\section{ANEXO}

\section{CONCORDANCIA DE PALABRAS:}

AMABILIS: Pr 24; 118, 5-6.6 - CDH I, 1; 48, 9 - II, 14; 114, 26.27 .29 - Or 4; 11 , $8-5 ; 13,5-6 ; 15,4-7 ; 20,55 ; 21,89 ; 23,131-8 ; 27,30-31$.

AMANTER: Or 6; 16, 25

AMARE: Mon 49; 64, 15.19.20.22.23-50; 65, 4.4.5.6.7-51; 65, 13.13.13.17.17-59; 70, 13. 13-60; 70, 20.27.29.29; 71, 2.4-61; 71, 21-67; 78, 2.5.9-68; 78, 13.18.24; 79, 1.3.4.5.8-69; 79, 11. 13.14.18.22.23.23.23.24.24.25.26.27; 80, 3-70; 80, 8.10.10.11.11.12.12.13.13.13.14.15.16.16.21. 22.22.24.26.27.27.28.30; 81, 4.4$71 ; 81,21 ; 82,1-72 ; 82,6.7 .8 .9-74 ; 82,22.23 ; 83,2.8-76 ; 83,16.18$ - Pr $1 ; 100$, $11.11 .13 .17-9 ; 107,23-23 ; 117,13-25 ; 118,16.18 .19 ; 120,9.15-26 ; 121,9.9-$ 10.11.12.14.23 - DV 8; 188, 10.11.13.15.16.17.18 - DLA 7; 219, 17-13; 225, 23 - Inc 1; 7, 1 - CDH Com; 41, 2 - I, 10; 65, 7.25.29-20; 87, 9 - II, 1; 97, 10.11.13.15.16.18.19.20. 21.22 - 13; 112, 28.29 - DCV 24; 167, 21 - W 4; 236, 24 - SA 0; 239, 14 - Conc I, 6; 257, 9 - III, 13; 286, 5 - Or 1; 5, 6.8-2; 6, $13.13 .16 .17-4 ; 12,48-6 ; 17,53-7 ; 18,6.11 ; 19,25 ; 20,53 ; 21,89-90 ; 23$, $135.144 ; 24,165 ; 25,192.196-9 ; 31,40-10 ; 39,175-11 ; 42,9 ; 44,64.65-12 ; 46$, 43.44.45.46; 47, 60.78.78.78-16; 64, 5; 66, 66; 67, 81-18; 71, 20 - Med 3; 84, $11 ; 89,147$.

AMATOR: Or 2; 9, 80-7; 25, 191.193-9; 31, 41.42-11; 44, 67-12; 47, 60.68 - 14; 61, 186- 16; 67, 87 - Med 2; 81, 34.39.

AMICA: Or 16; 67, 78.

AMICABILITER: SA 0; 239, 8 - Or 16; 65, 33.

AMICITIA: Pr 25; 119, 4

AMICUS: AZ 0; 223, 6 - W 3; 235, 15 - SA 0; 239, 2 - Or 8; 26, 10.14; 29, 94.105$10 ; 38,136-11 ; 42,9.25 .25 ; 43,38.47 ; 44,58.63 .64-12 ; 45,12 ; 46,39-13 ; 50$, 13-14; 52, 65.66.75-14; 56, 24; 61, 184-16; 65, 26-17; 68, 5; 69, 36-18; 71, 2.8.18; 72, 28-19; 73, 3; 75, 51 - Med 3; 84, 14.

AMOR: Mon 49; 64, 18-50; 65, 2.8.10-51; 65, 12.18-52; 65, 20.21.24-53; 66, 2.5.8.10.11-54; 66, 16.17.27-55; 67, 3.7.19.20-56; 67, 23.24; 68, 1.4.7-57; 68, 11.14.15.18.22.24; 69, 2.10-59; 70, 11.11.11.13.15-60; 70, 21.24; 71, 5-61; 71, 10.10.12.15.18.19.22-67; 78, 3-69; 79, 15-70;80, 17.17.18.18.19.20.26-71; 81, 9-10-77; 84, 11 - Pr 1; 98, 9-23; 117, 11.12-26; 121, 17 - DCD 12; 254, 24-23; 271, 9-24; 271, 24.28; 272, 2 - CDH Com; 41, 2 - I, 20; 86, 28; 87, 5 - Proc 1; 177, 12 - Conc I, 6; 257, 14 - Or Prol; 3, 3; 4, 7-2; 6, 3; 7, 21.23; 9, 73-5; 13, $21-6 ; 17,57-7 ; 18,3 ; 22,110 ; 24,159.164 .169 ; 25,182.192 .194-9 ; 31,41-11$; 43,$30 ; 44,65-12 ; 47,69.74 .74 .75$. 75; 48, 81.81; 49, 128-13; 52, 70-14; 58, 87-

(217) Es el sentido del admirable capítulo CDH II, 20, especialmente cuando Anselmo muestra al Hijo que dice al pecador condenado: "Llévame y redímete" (tolle me et redime te: p. 132, 3). 
16; 65, 32; 66, 53.70; 67, 80.80. 80.84.88-18; 71, 20; 72, 26-19; 74, 44 - Med 3; 84,$9 ; 89,151.152 ; 90,186 ; 91,192.196 .199 .202 .206 .208 .209$.

DILECTIO: Mon 78; 84, 17.18.20.24; 85, 1.4.4.6 - Pr 25; 120, 19 - CDH I, 3; 51, 2-6; 53, 3; 55, 2. 3-20; 87, 31 - II, 16; 118, 10 - DCV 0; 139, 10 - SA 0; 239, 4.14 - Or $1 ; 5,10-7 ; 24,158.160 ; 25,186.188-11 ; 42,6 ; 43,52 ; 44,59.60 .75 .82$ - $12 ; 45,3$. 5.6.17; 46, 22.23.40; 47, 63.64; 48, 87.88-13; 52, 72-16; 66, 65-18; 71, 19; 72, 25.32.38.41 - Med 3; 91, 200.208.

DILECTOR: Pr 25; 119, 17.17 - Or 11; 42, 22; 44, 57.72-12; 45, 13; 46, 28.39; 47, $59 ; 48,86-13 ; 52,61-14 ; 57,65-66$.

DILECTRIX: Or 16; 65, 16

DILECTUS: Or 2; 7, 32; 9, 73 - 9; 33, 88 - 11; 42, 4.5.5.10.21-22; 43, 37; 44, 56.60.74.77.78.78.80 - 12; 45, 16; 46, 27.28.35.38.41;47, 51; 48, 82.86; 49, 123 - $13 ; 51,52 ; 52,61.65-14 ; 57,65 ; 60,167 ; 61,190-15 ; 63,50-16 ; 64,9 ; 65$, $16.25 ; 66,61 ; 67,84-19 ; 73,21$

DILIGERE: Mon 51; 65, 12.18 - 52; 65, 22 - 53; 66, 7 - 78; 84, 21 - 80; 87, 10.10 Pr 25; 119, 5; 120, 5.10.14.17 - DV 12; 192, 1.1 - CDH I, 6; 54, 1.17; 55, 5 - 8; 60, 3 - 16; 74 - DCV 18; 159, 19 -SA 0; 239, 13 - Conc III, 1; 263, 21 - 2; 265, 16 - Or 7; 22, 95; 25, 185.185.186.186.186.187.188. 188.188.189.197 - 11; 43, $51 ; 44,53.69 ; 45,86$ - 12;45, 6.6.6.18.18; 46, 32.33.40.41.41.42; 47, 61. 61.68.76.79; 48, 82.97.97; 49, 125. 129.129.132 - 18; 71, 17.20.23; 72, 37.38. 40.41.44.45 - 19; 73, 21; 74, 32 - Med 1; 79, 98 - 2; 80, 20

\section{RESUMEN}

Anselmo es conocido como el Padre de la escolástica y se ve en él al hombre que dio a la razón sus letras de nobleza. Muy pocos le ven como un autor místico que quiere transparentar su experiencia de Dios y ayudar al lector a buscar su propio razonamiento en su propia experiencia. El trabajo busca presentar a Anselmo como teólogo del amor. Para esto se estudia el vocabulario afectivo en todas las obras de Anselmo, sobre todo la palabra 'amare' y sus derivadas.

El amor está presente en todas las obras de Anselmo. El amor es fundamental para entender las obras filosóficas como el Monologion, las obras teológicas como el Cur Dus Homo y las obras afectivas como las Oraciones. Cuando no habla de amor en sus obras, Anselmo insiste en buscar la verdad que es Cristo y así entregarse totalmente a Él.

Lo que busca Anselmo es esclarecer el enigma del hombre. Su intuición básica es que el enigma se resuelve no en el espejo (que muestra la persona en su inversa), sino en el cara a cara con Dios. Este encuentro con el Dios de amor es el fundamento de su visión antropológica. También de su visión cristológica: Cristo es el hombre que se entrega totalmente por amor.

\section{ABSTRACT}

Anselm is known as the father of the scholastical and we see him the man who gives to the reason its letters of nobleness. Few persons see him like a mystic author who wants to show through his experience on God and help the reader on searching his own argument in his own experience. The paper try to introduce Anselm like the theologian of love. For that reason all the affective lexicon is studied in all the Anselm's plays (specially the word 'love' and its derivatives). 
The love is showed in all the Anselm's plays. The love is fundamental in order to understand the philosophical plays like the 'Monologion', the theological plays like the 'Cur Deus Homo' and the affective plays like the Prayers. When he doesn't speak about love in his plays, Anselm persists on searching the truth. That is Christ y so surrender completely on him.

Anselm search to lighten the enigma of the man. His basic intuition is: the enigma isn't solved at the mirror (it shows the person at inverse). It resolves face to face with God. This finding with God of love is the reason of his anthropological sight and of his Christological sight too. Christ is the man who delivers all of us up for love. 